\title{
Cancer stem cells as key drivers of tumour progression
}

Ain Zubaidah Ayob ${ }^{1}$ and Thamil Selvee Ramasamy ${ }^{1,2^{*}}$

\begin{abstract}
Background: Cancer stem cells (CSCs) are subpopulations of cancer cells sharing similar characteristics as normal stem or progenitor cells such as self-renewal ability and multi-lineage differentiation to drive tumour growth and heterogeneity. Throughout the cancer progression, CSC can further be induced from differentiated cancer cells via the adaptation and cross-talks with the tumour microenvironment as well as a response from therapeutic pressures, therefore contributes to their heterogeneous phenotypes. Challengingly, conventional cancer treatments target the bulk of the tumour and are unable to target CSCs due to their highly resistance nature, leading to metastasis and tumour recurrence.

Main body: This review highlights the roles of CSCS in tumour initiation, progression and metastasis with a focus on the cellular and molecular regulators that influence their phenotypical changes and behaviours in the different stages of cancer progression. We delineate the cross-talks between CSCs with the tumour microenvironment that support their intrinsic properties including survival, stemness, quiescence and their cellular and molecular adaptation in response to therapeutic pressure. An insight into the distinct roles of CSCs in promoting angiogenesis and metastasis has been captured based on in vitro and in vivo evidences.

Conclusion: Given dynamic cellular events along the cancer progression and contributions of resistance nature by CSCs, understanding their molecular and cellular regulatory mechanism in a heterogeneous nature, provides significant cornerstone for the development of CSC-specific therapeutics.
\end{abstract}

Keywords: Cancer stem cells, Resistance, Stemness, Tumour microenvironment, Extracellular matrix, Hypoxia, Exosomes, Quiescence, Angiogenesis, Metastasis

\section{Background}

Despite the progress being made in the treatment for cancer, cancer remains one of the most common causes of death globally. Cancers are most likely curable when they are diagnosed at the earlier stage through conventional treatments such as surgery, chemotherapy and radiotherapy. However, many cancers are also diagnosed at a later stage, during which the cancer have become progressive and metastasize to other organ. Even if the cancer is diagnosed and treated at earlier stage, some residual cells still remain and following some time, may cause tumour recurrence and the cancer often becomes

\footnotetext{
* Correspondence: selvee@ummc.edu.my

${ }^{1}$ Stem Cell Biology Laboratory, Department of Molecular Medicine, Faculty of Medicine, University of Malaya, 50603 Wilayah Persekutuan Kuala Lumpur, Malaysia

${ }^{2}$ Cell and Molecular Laboratory (CMBL), The Dean's Office, Faculty of Medicine, University of Malaya, 50603 Wilayah Persekutuan Kuala Lumpur, Malaysia
}

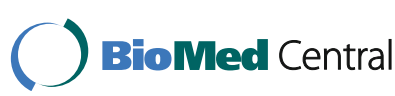

(c) The Author(s). 2018 Open Access This article is distributed under the terms of the Creative Commons Attribution 4.0 International License (http://creativecommons.org/licenses/by/4.0/), which permits unrestricted use, distribution, and reproduction in any medium, provided you give appropriate credit to the original author(s) and the source, provide a link to the Creative Commons license, and indicate if changes were made. The Creative Commons Public Domain Dedication waiver (http://creativecommons.org/publicdomain/zero/1.0/) applies to the data made available in this article, unless otherwise stated.

more aggressive which leads to metastasis. Growing evidence have implicated that these residual cells which could be found during any stage of cancer progression that are responsible for causing the therapeutic resistance, possesses stem-like properties/functions known as the cancer stem cells (CSCs). Hence, this population of cells represents the critical subset within the tumour mass in perpetuating the tumour, even after what seems to be effective therapy and leads to tumour aggression. In the recent decades, the CSC theory generates much attention and excitement, whereby scientist believed this theory will revolutionize our understanding of the cellular and molecular events during the cancer progression contributing to therapy resistance, recurrence and metastasis. The CSC theory of cancer progression presents tumour as a hierarchically organised tissue with CSC population at the top rank in the hierarchy, that then generate the more differentiated bulk of the tumour cells with lower or 
limited proliferative potentials $[1,2]$. CSCs share similar properties with normal stem cells, including the ability to self-renew and differentiation that give rise to heterogeneous, differentiated cancer cells making up the bulk of the tumour. Due to this similarity, CSCs are commonly characterised by the expression of surface markers associated with stem cells, such as CD133, CD44, CD90, and side population cells (SP) by which they can be isolated an enriched in vitro and in vivo, although no single marker can be used to define the CSC populations [2]. Also, their tumorigenicity potential is characterised by their enhanced ability to repopulate the original tumour when transplanted into immunodeficient mice even at low clonal density. Additionally, sphere forming assay were also used as an in vitro assay for the identification and enrichment of CSCs whereby only fractions of cells from solid tumours such as brain, breast, colon et cetera forms neurospheres, mammospheres and colonospheres respectively [3].

Despite extensive studies, there have been on-going controversies on the origin of CSCs, whether they arise from normal stem cells or non-stem cells [2, 4]. Additionally, their true phenotypes and functions remain argumentative. However, if the hypothesis of CSC being resistant population of cells is accepted, it may be possible that these cells are either; i) quiescent, non-dividing cells hence conferring their insensitivity, or ii) proliferative CSCs, but insensitive to the chemotherapy due to activation of resistance mechanisms. While many studies demonstrated that de novo CSCs exist in the tumour mass, it has also been proposed that CSCs is dynamic cellular states, a mechanism whereby acquisition of stem-like traits is necessary for them to be resistant and promotes tumour progression $[5,6]$. Nevertheless, the tumour microenvironment plays an integral part during the tumour progression and metastasis, therefore presumed to support the cellular fate of CSCs [7].

Tumour progression involves complex cellular and molecular processes that are preceded by the initial genetic and epigenetic alteration causing the transformation to cancer cells. Conceptually, cancer can be divided into the following stages: initiation, promotion and progression and these stages are concomitant with complex and dynamic cellular events [8], as summarised in Fig. 1. Given the

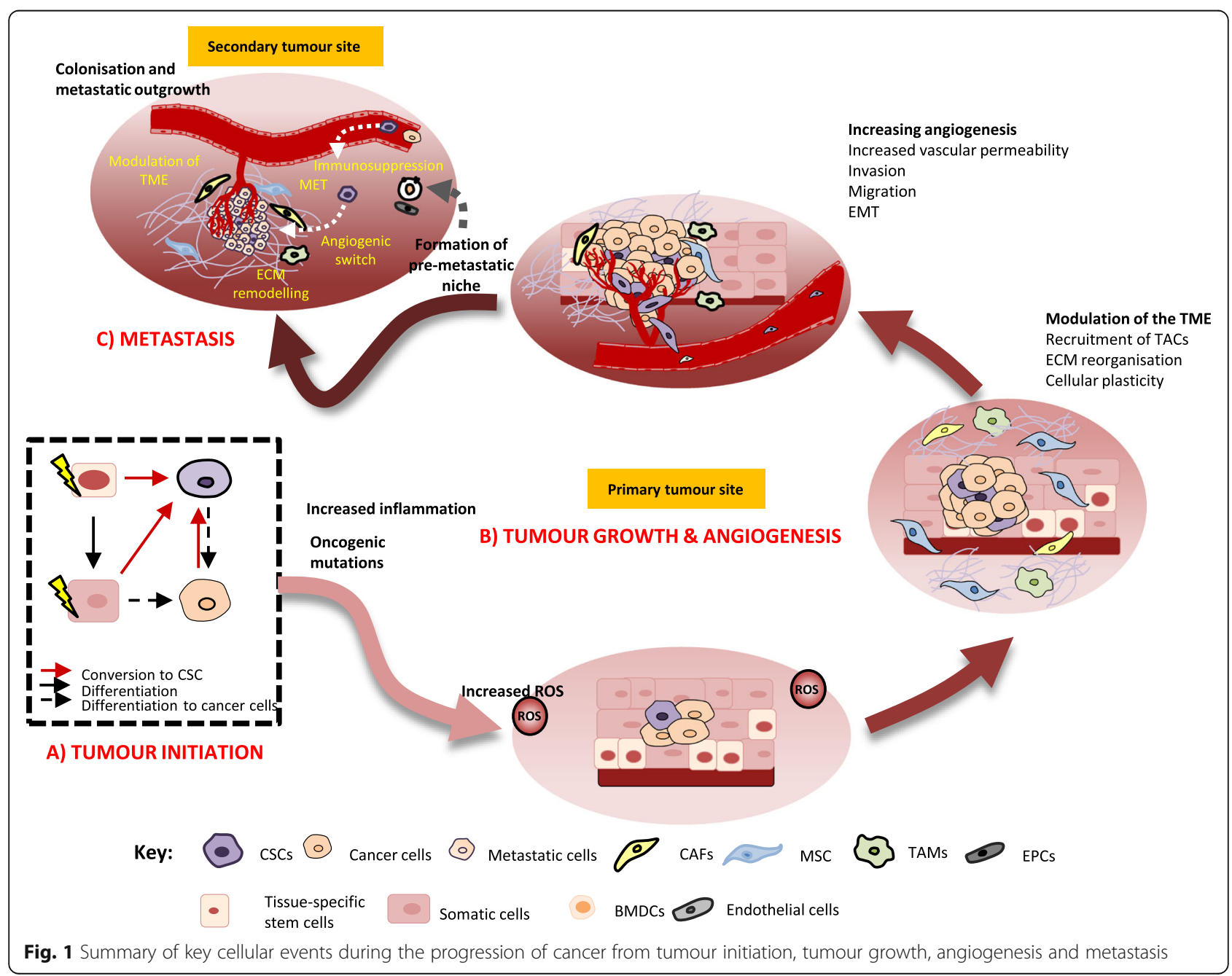


constant change in the structure and anatomy of the tumour as cancer progresses, increasing evidence shows that CSCs also changes in response to these dynamics, as an adaptive response for their survival [9]. This review therefore aims to dissect the behaviours and the roles of CSC; their regulation throughout the tumour progression, and the phenotypical outcomes resulting from these behaviours. Integral to the concept of tumour heterogeneity in cancer progression, CSCs therefore play an active role throughout the cancer progression as well as in therapy resistance by manipulating their intrinsic and extrinsic adaptation, favouring their growth and survival. Therefore, better understanding of CSCs behaviours, which differs according to their microenvironment corresponding to the different stages of cancer, is important in order to better devise more effective therapeutic strategy targeting these populations.

\section{CSC in tumour initiations}

Carcinogenesis involves series of events, often initiated with cells losing their growth control due to accumulated mutations, leading to uncontrolled proliferation. This usually involves the alteration of gene such as oncogenes, tumour suppressor genes as well as those involved in DNA repair mechanisms. Subsequently, additional mutation results in the clonal selection with more aggressive phenotypes [10]. With no therapeutic intervention, the cancer becomes increasingly progressive, facilitated by the surrounding tumour microenvironment providing tumour growth supportive signals, the cancer no longer remains localised but begins searching for new soil for them to compensate increasing needs to survive, via a metastatic cascade. In this milieu, research has suggested that cancer cells are capable of influencing their surrounding tumour microenvironment to make it permissive for them to survive and evolve with more resistant and aggressive phenotypes as the cancer progresses. These events implicate why treatment outcomes are relatively poor and are more difficult to manage when patients are diagnosed at a higher stage of cancer. In another case, cancer may, more often, increase in aggression following therapeutic intervention such as chemotherapy, due to the presence of subpopulation of stem-like cells with resistance properties, subsequently capable of re-initiating the tumour, causing tumour relapse.

When the field of cancer research is 'renewed' with the CSC theory, whereby a subset of cells with stem cell properties are responsible for the perpetuation of cancer, a great amount of research has been done in identifying CSCs and understanding the mechanisms underlying their formation and thus, their roles in cancer initiation. Studies by Dick group in 1994 showed that leukemiainitiating stem cells present in the acute myelogenous leukemia (AML) patients could induce AML when transplanted into severe combined immunodeficient (SCID) mice [11]. The presence of stem cell in cancer were further supported in other studies in breast cancer [12], brain [13] and subsequently other types of cancers. Due to their having the self-renewal capacity and differentiation capacity in driving the tumour growth, CSCs are hypothesised to be originated from the normal stem cells/progenitor cells of the tumour tissues. Under normal physiological condition, normal stem cells usually reside in a quiescent state which is maintained by a specialised niche. Only upon receipt of a stimulating signal, the stem cells become activated to divide and proliferate. Any genetic mutation causing stem cells to become independent of growth signals, or to resist antigrowth signals, will cause the stem cells to undergo uncontrolled proliferation and possible tumorigenesis [4]. Direct evidence of the roles of CSC in cancer initiation is drawn from the many studies demonstrating the capacity of isolated CSCs, characterised by their positive expression of stem cells markers, to repopulate the parental tumour in immunodeficient mouse even at very low number whereas their negative, non-CSC counterpart does not exhibit similar tumorigenicity [14]. These studies supported one of the modes of CSC initiation, whereby transformed normal stem cells or progenitor cells could give rise to the formation of CSCs. Further insights into the mechanisms of CSC in cancer initiation have unravelled the roles of stemness transcription factors. For example, in a mouse model of skin carcinogenesis, Blanpain and colleagues demonstrate a key role for the transcription factor SOX2 in initiation and progression of melanoma. SOX2 is not expressed in normal skin, but it appears at an early stage in tumour formation. Tumour initiation can be prevented by deletion of the Sox2 gene. In addition, SOX2-expressing cells function as tumour propagating cells upon transplantation, while the removal of SOX2-postive cells from established tumours leads to regression. SOX2 appears to be able to contribute to both tumour initiation and progression by directly regulating genes involved in cancer functions such as stemness, proliferation, survival and invasion [15].

\section{Role of inflammation in cancer initiation}

Central to all cancers is inflammation and that the cell processes involved in inflammation not only are responsible for initiation of the cancer, but also persist during its growth and play a central role throughout every phase of the cancer's existence, including progression, invasion, angiogenesis, and metastasis [16, 17]. Carcinogenic events and conditions such as chemicals, obesity, hyperglycaemia, persistent infections, autoimmune diseases, and carcinogenic heavy metals, are known to promote inflammation [18] . Indeed, up to $20 \%$ of human cancers are 
accompanied with underlying virus infection; for example human papillomavirus (HPV-cervical carcinoma), herpes virus (lymphoma), hepatitis B and C (hepatocellular carcinoma), cytomegalovirus (glioblastoma), and Helicobacter pylori (gastric cancer) promote cancer development by inducing chronic inflammation [19]. Under inflammatory conditions, ROS and RNS can induce the formation DNA lesion products, including 8-oxo-7,8-dihydro-2'-deoxyguanosine (8-oxodG) and 8-nitroguanine respectively, which is considered to be mutagenic [20]. While it is known that multiple mutations accumulating over time are responsible for the malignant transformation of cells, there is significant evidence that increased generation of inflammation inducing factors such as reactive oxygen species (ROS), reactive nitrogen species (RNS), and lipid peroxidation products (LPPs) are the underlying damaging elements [17].

To link the possible roles of inflammation and CSC in the cancer initiation, evidence can be drawn from the changes in the microenvironment within the stem cell niche. It has been observed that the formation of CSCs is preceded by the transition of the stem cell niche into an area of high concentrations of ROS and RNS, LPPs, inflammatory cytokines and chemokines [17, 21]. Prolonged exposure of these stem cells' DNA to assaults by ROS/RNS and LPPs can produce varying degrees of genetic mutations that over time is beyond repair, and these cumulatively may drive the conversion a stem cell into a cancer stem cell $[20,21]$. Additionally, accumulating studies identifies co-localisation of CSC markers in inflammationrelated cancers, as summarised in review by Ohnishi et al. [20], suggesting the possible roles of inflammation inducing CSCs. For example, expression of Oct3/4 and CD44v6, have been shown to be correlated in urinary bladder cancer induced by Schistosomahaematobium (SH) infection [22], whereas higher CD44v6 expression alone correlates with urinary bladder without the infection [22, 23]. In the same study, the authors also demonstrate that nuclear localisation of cyclooxygenase-2 (COX2) is associated with the upregulation of these stemness markers [23]. COX2 mediates the activation of prostaglandin E2 (PGE2) signalling, which is also involved in the inflammationinduced activation of normal stem cells or CSCs [24]. This $\mathrm{SH}$-infection induced inflammation causing iNOSindependent DNA damage, promotes the expansion of mutant stem cells, via NF- $\mathrm{kB}$ activation leading to tumour development [25]. Similarly, cholangiocarcinoma tissues with underlying Opithorcis viverrini infection positively express CD133 and Oct $3 / 4$, suggesting stem cells are involved in the initiation of cancer via inflammatory inductions [26].

Taken together, transformation of the normal stem cells or progenitor cells may define a key event in the derivation of CSCs thus directly contributes to the initiation of cancer. The underlying inflammation and oxidative stress induction represent key event leading to the accumulation of mutational events acquiring the CSC phenotypes, however their mechanisms need to be further explored. Importantly, acquisition of these stem-like, CSC phenotypes also occurs in the more differentiated cancer cells as the cancer becomes more progressive predominantly through the interactions with the microenvironment, which will be discussed further in the next section.

\section{CSCs in tumour growth and angiogenesis}

As the tumour develops, it becomes increasingly important for the cancer cells to sustain their growth and functions achieved through formation of tumour microenvironment by recruiting cellular components and modulating their extracellular matrix (ECM). Additionally, the tumour mass is increasingly hypoxic due to increase in tumour size, causing the formation of new vasculatures to facilitate diffusion of nutrients and oxygens to the cancer cells through angiogenesis process. Thus, the niche plays key roles in CSCs maintenance by regulating their stemness properties via activation of key signalling pathways involved in the self-renewal, angiogenesis and promotes the long-term survival of CSC. CSCs however, do not play the passive roles of becoming the receiving ends but they work together in modulating the niche in their favour predominantly through their interactions with the components in the niche. As a mechanism of adaptation, CSCs can interact with their micro-niche to modulate their survival, growth and metastatic regime/desire in a stressful therapeutic pressure, an unfavourable environment especially during and after cancer treatments. Importantly, cancer cells and CSCs "educate" the surrounding cells such as the stromal and immune cells by secreting signals that recruit, transform and alter the functions and activities of the surrounding cells which in turn facilitate growth and progression of tumour [27]. This interactions, occurring through both cell-cell or ECM-cell communication ensures the niches balance between self-renewal, differentiation and resistance properties of CSCs [28]. These interplay of the different factors in the tumour microenvironment, including therapeutic pressures can also promote the induction of CSCs from non-CSCs, and seems to be mediated by common signalling pathways predominantly the Notch, NF- $\mathrm{kB}$, TGF- $\beta$, Wnt $/ \beta$-catenin, and MAPK signalling pathways, to name a few [29-31]. The regulation of the CSCs characteristics through these pathways by the different microenvironmental factors can be distinguished by the different mediators/effectors in eliciting the CSCs' self-renewal and tumour promoting functions [31]. So how do these interactions promote tumour progression and what roles does CSC play in these interactions? In the next section, we highlight the interplay between CSCs and the niche components, including the tumour-associated cells (TACs), ECM, hypoxia and therapeutic pressures that contribute to 
the CSC characteristics and subsequently tumour progressions.

\section{Interactions with the cellular components in the tumour microenvironment}

The key cellular components in the tumour milieu include the cells of mesenchymal origin such as cancer-associated fibroblast (CAFs), mesenchymal stem cell and endothelial cells and as well as of hematopoietic origins such as the macrophages, T-cells and natural killer (NK) cells. The cancer cells, CSC and TACs establish cytokine network that supports the maintenance of CSCs as well as promoting the formation of new CSCs, thus facilitating tumour survival, propagation as well as recurrence [32].

CAFs are resident cells within the tumour stromal which results from recruitment and transformation during tumour progression, supporting CSC function through autocrine and paracrine secretion of cytokines factors, as shown in Fig. 2. Cancer cells-derived secretory molecules, such as basic fibroblast growth factor (bFGF), transforming growth factor beta (TGF- $\beta$ ), platelet-derived growth factor (PDGF), and interleukin- (IL-) 6, transform surrounding fibroblast into CAFs [33-36], and in turn, CAFs promote tumour growth as well as sustain the stemness property of CSCs in a paracrine manner. Compared to normal fibroblast, CAFs are characterised by increased proliferation, enhanced production of ECM proteins and unique cytokines production [37]. In mammary tumour of murine models, Valenti et al. shows that CSC mediates the activation of CAFs via activation of hedgehog signalling [38]. In return, CAFs elicit their roles to maintain the self-renewal, expansion and plasticity of CSCs through paracrine signalling activation. For example, CAFs were shown to promote cancer stemness via the paracrine activation of $\mathrm{Wnt} / \beta$-catenin and Notch pathways mediated by HGF in colon and liver cancer respectively $[39,40]$. Studies have also demonstrated that CAFs are also involved in regulating the plasticity and maintain stemness properties of CSC by inducing epithelial mesenchymal transition (EMT), via paracrine secretion of TGF- $\beta$, stromal-derived

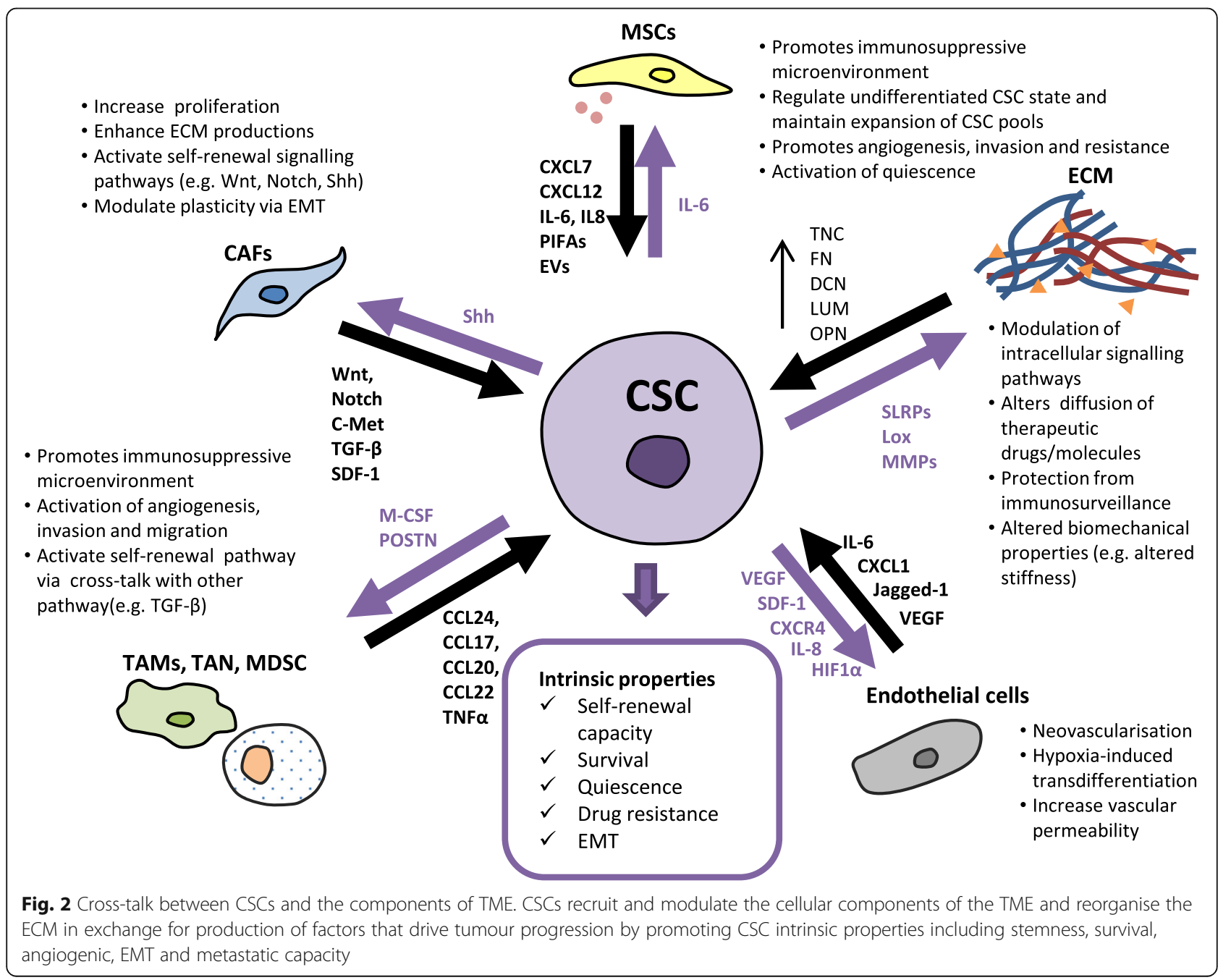


factor 1 (SDF-1) [41, 42] and production of matrix metalloproteinase protein 9 (MMP9) [34].

Mesenchymal stem cell (MSC) is another key cellular player that cross-talk with CSCs to promote tumour progressions by enhancing proliferation, fostering angiogenesis, promoting metastasis and most notably are responsible for generating an immunosuppressive microenvironment. For example, CSCs in breast cancer produce cytokines such as IL-6 to attract the MSCs, which then produce CXCL7. This key cytokine, in turn, induces the production of many other cytokines by tumour cells to support the growth of CSCs while suppressing immunological cascade [43]. MSC also promotes stemness through NF- $\mathrm{kB}$ pathways via secretion of CXCL12, IL-6, and IL-8 [30]. MSC stimulates tumour progression by production of Gremlin1 to promote undifferentiated state [44]. MSC also causes aberrant regulation of microRNA associated with CSC maintenance and survival. For example, MSC promotes the CSC properties by upregulating the expression of miR-199a, subsequently causing deregulated expression of a network of microRNAs and suppressed Forkhead box protein P2 (FOXP2) [45]. Evidence has demonstrated the roles of MSC in drug resistance, mediated by the release of platinum induced fatty acids (PIFAs) responsible for their platinum drug resistance; activation of SDF- $1 \alpha / C X C R 4$ signalling or by converting themselves into CSCs [46]. Cross talk between both CSC and MSC established through extracellular vesicles (EV) or exosomes secretion is implicated to facilitate tumour angiogenesis, invasion, drug resistance, as well as activation of dormant or quiescent cancer cells [47, 48]. MSC-derived EV (MSC-EVs) has been shown to elicit both tumour promoting and inhibitory effects, whereby it can enhance the tumour growth and metastasis, or they may promote apoptosis of cells and cause tumour regression [48-51]. For example, MSCderived EV can induce the activation of ERK1/2 signalling pathway to promote growth of renal carcinoma, leading to the progression from the G0/G1 to $S$ phase of the cell cycle [52]. Additionally, MSC-EVs were also shown to promote the metastatic phenotypes in MCF7 breast cancer cell line, which is achieved by activating signalling pathways including ERK1/2 [53] and Wnt/ $\beta$-catenin pathways [54], suggesting the enrichments of CSC phenotypes.

The tumour microenvironment is also characterised by chronic inflammation that promotes the tumour proliferation and metastasis through immunosuppression and evasion from immune surveillance [55]. Cancer cells and CSCs promote an inflammatory niche by secretion of chemokines and cytokines to recruit tumour-associate macrophages (TAM), tumour associated neutrophils (TANs), and myeloid-derived suppressor cells (MDSCs). For example, IL-13, IL-34 and osteoactivin derived from cholangiocarcinoma CSCs sphere conditioned media could promote the activation of $\mathrm{CD} 14+$ macrophage with TAM- like features and exhibit in vivo tumour promoting effect [56]. In other instance, glioblastoma stem cells secrete periostin (POSTN) to recruit M2 macrophage-tumour supportive macrophage, and disruption of POSTN leads to the specific inhibition of the tumour-supportive M2 types of TAMs in xenografts [57]. Additionally, TAMs elicit their pro-tumour activity by activation of angiogenesis and promotes migration and invasion via induction of EMT. For examples, production of chemo-attractants by TAMs such as CCL24, CCL17, CCL20, CCL22 stimulate proangiogenic capacity, in response to macrophage colony stimulating factor (M-CSF) secreted by tumour cells [58, 59]. TAMs and CD4+ T cells secrete TNF $\alpha$ which upregulates NF- $\mathrm{kB}$ signalling pathways to induce EMT-associated transcription factors such as Slug, Snail and Twist, increasing the crosstalk with the TGF- $\beta$ signalling pathway promoting self-renewal, migration and invasion of CSCs. Recently, exosomal transfer of microRNA have been implicated to modulate the activation and reprogramming of TAMs $[60,61]$ and in return, TAM-derived exosome transfer of miR-21 confers drug resistance in gastric cancer cells [62].

\section{Role of hypoxia in tumour progression}

Hypoxia is one of the key features of solid tumour characterised by reduced oxygen levels $(<2 \%)$, resulting from high oxygen demand from proliferating cancer cells and low oxygen supply due to irregularities in tumour vascularization or distance from supporting blood vessels. Hypoxia-inducible factors (HIFs), including HIF1 $\alpha$ and HIF2 $\alpha$ represents the primary mediators for the cellular response to hypoxic condition by regulating diverse cellular processes during cancer progression including survival, proliferation, metabolism, EMT, angiogenesis and metastasis $[63,64]$. High expression of HIFs have been correlated with poor prognosis in various tumour types $[65,66]$. With respect to the roles of CSCs in cancer progression, the hypoxic conditions were also linked in regulating the CSCs biology including in the maintenance of self-renewal/stemness, EMT, quiescence and drug resistance properties [67]. Several reports using in vitro studies have indicated nonCSCs also acquire the stem-like characteristics through the expression of genes such as OCT4, SOX2 and NANOG, which is required for the maintenance of self-renewal in stem cells or the activation of the Notch signalling pathway that regulates cell self-renewal and differentiation [68-70]. Intriguingly, the hypoxia-associated CSC enrichment have been shown to be primarily dependant on the HIF2 $\alpha$ pathway [71]. Other signalling pathways implicated in the regulation of stemness phenotypes by the HIFs included the TGF- $\beta$, Wnt/ $\beta$-catenin, TNF $\alpha$ and NF-kB [72-74]. Activation of these signalling pathways is also implicated in the induction EMT via the transcriptional control of EMTassociated transcription factors such as SNAIL, TWIST, 
ZEB1, SLUG and TCF3 [75, 76]. Additionally, hypoxic condition also promotes high ROS in the tumour microenvironment, subsequently leads to the activation of stress signalling in CSC mediated by TGF- $\beta$ and TNF $\alpha$ signalling pathway that maintain their undifferentiated state [77-79]. Under hypoxic condition, both the CSCs and stromal cells activate their HIF genes, which are the primary factors that drive angiogenesis via the induction of VEGF $[55,80]$. Given that the maintenance CSCs are not only favoured but enriched under hypoxic condition, the development of therapeutics targeting the HIFs and the associated pathways represent an attractive approach to target these populations.

\section{Tumour angiogenesis}

TACs collectively support the angiogenesis during the tumour progression and this process predominantly involves endothelial cells and pericytes [81]. Cross-talks between endothelial cells and CSC, established through their proximity with the blood vessel, predominantly support angiogenesis via secretion of pro-angiogenic factors, and promote the expansion and maintenance of CSC phenotypes and survival via juxtacrine signalling activation of self-renewal pathways [82-84]. For example, endothelial cells promote the expansion of CSCs via expression of soluble form of Jagged-1 and Shh ligands to activate the Notch and Sonic Hedgehog pathways respectively [85, 86]. Human oesophageal cancer endothelial cells can enhance migration, invasion and self-renewal properties of oesophageal carcinoma cell in vitro by a direct cell-cell interaction through enhance epiregulin expression [87]. Krishnamurthy et al. observed that IL-6 levels in tumourassociated endothelial cells define the tumorigenicity of CSC in head and neck squamous cell carcinomas, as evidenced by enhance sphere formation and promotes stemness phenotypes via phosphorylation of STAT3 pathway [88]. In lymph nodes associated metastasis, lymphatic endothelial cells promote angiogenesis and lymphangiogenesis via secretion of CXCL1, increasing vascular permeability in pre-metastatic organs as well as mediate immunosuppression by recruiting immature dendritic cells via CCL21 expression $[89,90]$. The angiogenic activity of endothelial cells is also regulated by diverse microRNA that has been shown to have both pro and anti-angiogenic activities [91]. Endothelial cells are also shown to induce EMT which confers them stem cell properties and lower sensitivity towards anti-cancer drugs [92, 93]. In return for this interaction, CSC also preferentially upregulates pro-angiogenic factors such as VEGF, stromal derived factors 1 (SDF-1), interleukin 8 (IL-8) and CXCR4 to drive the angiogenesis process [94]. Emerging evidence demonstrated that CSC also actively involved in angiogenesis by transdifferentiating into functional endothelial cells, shown in breast CSC [95] and glioma stem cells [96-98]. Study by
Soda et al. found that glioblastoma initiating cells transdifferentiate into endothelial cells induced by a hypoxia activation of HIF- $1 \alpha$, but interestingly is independent of VEGF expression [98]. In another study, Wang et al. and Ricci-Vittiani et al. demonstrated that endothelial cells share similar genetic alteration in glioblastoma stem-like cells, and that these CSC-like cells could be induced to transdifferentiate in a Notch-dependant manner [96, 97]. These studies altogether suggest the roles of CSCs in promoting angiogenesis by directing their fate into the endothelial lineages. Thus, the development of antiangiogenic therapy may have to be re-strategized as we begin to unravel the lineage plasticity of CSCs capable of creating their own vascular system to maintain stemness and their tumorigenicity.

\section{Reorganisation of the extracellular matrix component}

Other than the cellular component, the tumour microenvironment also comprises of non-cellular component that maintains the behaviour of the malignancy, which is the ECM. The ECM is a key component in the tumour microenvironments that mediates the cross talks between tumour cells and the microenvironment to promote malignant phenotypes. ECM components in the niche comprised of macromolecules such as collagens, glycoproteins and proteoglycans as well as integrins [99]. The ECM mediates extracellular cues from the microenvironment to maintain the stemness properties of CSCs, or direct their differentiation into heterogeneous tumour phenotypes, through the regulation of signalling pathways [99]. Cancer cells and CSCs design their own microenvironment by extensive overexpression of various matrix components, to support their growth and behaviours such as altering the diffusion of therapeutic drugs and other cytotoxic molecules [100]. For instance, deregulated expression of tenascin-C (TNC), which is one of the ECM proteins in stem cell niche, has been associated with their roles in cancer progression such as angiogenesis [101], invasion [102] and metastasis [103]. Increased TNC expression has been shown to correlate with poor prognosis and decreased survival in glioma patients [104], and was identified as potential biomarker for CSCs in glioblastoma [105]. Overexpression of TNC has been shown to play a role in driving cancer progression and drug resistance in melanoma enriched with stem-like SP cells, and knockdown of TNC decreased the SP cells fractions and sensitize them to doxorubicin treatment [106] Moreover, breast cancer cells supports their metastatic initiating ability by overexpressing TNC, by enhancing the regulator of stem cell signalling musashi homolog 1 (MSI1) and leucine-rich repeatcontaining G protein-coupled receptor 5 (LGR5), suggesting this cancer cells derived TNC supports the metastaticinitiating breast cancer cells through enhancing the selfrenewal pathways [103]. Additionally, Jachetti et al. 
demonstrated TNC protects prostate stem-like cells from immunosurveillance during dissemination via the suppression of T-cell receptor-dependent T-cell activation [107]. Similarly, Farace et al. demonstrated that the small leucinerich proteoglycans (SLRPs) decorin (DCN) and lumican (LUM) is upregulated in CSCs enriched spheres derived from glioblastoma and neuroblastoma [108]. They also found that these increased in SLRPs is concomitant with acquisition of resistance to temolozomide drug, quiescent phenotypes and induce cellular heterogeneity by promoting dedifferentiation of cancer cells towards stem-like phenotypes, allowing their survival in ensuring the progression of cancer [108].

Indeed, ECM molecules and their associated receptors modulate the CSC behaviours not only through modulation of cell-cell signalling and their immunomodulatory roles, but the biomechanical properties of the ECM also determine how a cell senses and perceives external forces and thus provides major environmental signals that regulate cell behaviours. Alteration and remodelling of ECM structure is done by enzymes that digest the ECM, which are secreted within the tumour microenvironment. CAFs play key roles in altered activities of ECM remodelling enzymes and deregulated ECM metabolism through elevated expression of MMPs to mediate the degradation of ECM to facilitate cancer cells invasion $[109,110]$. On the other hand, it has been shown that the ECM in the tumour stroma is typically stiffer compared to normal stroma, indicating the ECM biomechanical properties changes under different stroma condition and hence are constantly changing to drive the tumour progression [111, 112]. Under hypoxic condition, expansion of stem like cells is concomitant with 10-fold increase in LOX expression which is involved in generating the cross-linking molecules in the ECM, suggesting the role of CSC in promoting the stiffening of the tumour stroma facilitated by hypoxic microenvironment [59]. This suggests that the dynamics in the ECM deregulation promote the cancer progression, partly by expansion of CSCs, therefore may be a likely target for development of CSC-based therapeutics.

\section{Drug-induced resistance}

Tumour relapse remains the biggest challenge for the management of cancer patient as often this is accompanied with more aggressive cancers and metastasis. Chemotherapy remains one of the main therapeutic modalities; however, the effectiveness is limited by chemoresistance. Resistance can be classified into two categories namely the intrinsic (de novo) and acquired resistance [113].

One of the most important features pertaining to the CSCs properties is their ability to resist to conventional therapies. The postulation that some cells remain following therapeutic pressures suggest the de novo population of cells that is unresponsive to the treatment, whereby the residual cells are enriched with the stem-like properties causing the tumour relapses and metastasis, suggesting the role of CSC $[29,114,115]$. Molecular mechanisms of chemoresistance in cancer have been well described which includes increased drug efflux rate, altered drug metabolism their ability to resist DNA damage due to enhanced repair capacity. Epigenetic changes as well as the influence from tumour microenvironments providing survival signals also contribute to chemoresistance $[116,117]$. The presence of CSCs has been described as the mechanism through which chemoresistance is implicated, however many parallels have also been found to be associated with the aforementioned mechanisms. For example, CSCs are intrinsically resistant to conventional chemotherapies due to high expression of ATP-binding cassette (ABC) transporter proteins [118-120], enhanced aldehyde dehydrogenase (ALDH) activity [121], increased expression of anti-apoptotic proteins such as Bcl-2 and $\mathrm{Bcl}-\mathrm{X}_{\mathrm{L}}$ [122], enhanced DNA damage repair by activation DNA damage checkpoints such as CHK1 and CHK2 [123] and activation of key pro-survival signalling molecules [124, 125]. These establish that the acquisition of stemness traits is strongly associated with resistant or unresponsive properties in cancer.

Particularly, the quiescence nature of CSCs is of the interest of much research as this implies that treatment failure is inevitable as long these quiescence cells are present in the tumour bulk. Quiescence properties are often associated with stemness, as the normal stem cells reside in the G0/G1 stage of the cell cycle progression is a protective mechanism from cytotoxic stress [126]. In normal stem cell, cellular quiescence is an actively maintained and regulated state of the cells through a controlled signaling pathways and molecular regulators [126]. These include tumour suppressor p53 and retinoblastoma protein $(\mathrm{RB})$, cyclin-dependent protein kinase inhibitors (p21, p27, and p57), Notch-related pathways, and a number of miRNAs (such as miR-126, miR-31 and miR-489) [126]. Using retention of DNA label or lipophilic dyes, the presence of quiescence CSCs have been demonstrated in many in vitro and in vivo studies of breast [127], liver [128], melanoma [128], glioblastoma [129, 130] and ovarian cancer [131, 132]. Activation of p21 via BMP signaling is one mechanism for resistance to chemotherapy- and radiation-induced cell damage [133]. However, in order to develop a therapy that targets these quiescence CSCs, one have to ask these questions: 1) Does these quiescence cells represents pre-existing population in the tumour? 2) Or is quiescence a result of cellular response of pre-existing, non-quiescence CSC in response to the therapy; or 3) does the cancer treatment selectively induce non- CSC to become quiescence, hence becoming unresponsive to the treatment? This quiescence-associated resistance also implies the temporal nature of CSC enrichment, in addition 
to different molecular mechanisms and therefore requiring a careful strategy to develop the therapy.

Regardless, these resistance and stemness-induced drug response often result in more aggressive phenotypes, which subsequently lead to tumour relapse and metastasis. The acquisition of these aggressive phenotypes is prominently implicated by the acquisition of mesenchymal phenotypes through the epithelial mesenchymal transition (EMT) [134-136]. Activation of EMT through the transcription factors mainly Snail, Twist, Slug, and Zeb is mediated through various signaling pathways, however common signaling pathway that have been implicated is through the TGF $/$ Smad, PI3K/AKT, ERK1/2, inflammatory associated NF- $\mathrm{KB}[137,138]$ pathway as well as the self-renewal pathways; WNT/ $\beta$-catenin and Notch pathway [139]. Activation of EMT is also implicated as a molecular program in the initiation of metastasis, which causes the cancer cells to gain invasive and migratory potentials. In a report by Lee et al., treatment with chemotherapy drugs induced adaptive drug resistance and increased CXCR $4^{\text {high }}$ cells with metastatic potential in ovarian cancer cell lines, whereas removal of drugs causes the cells to revert the state transition. Additionally, CXCR4 $4^{\text {high }}$ cell exhibits dormancy in drug resistance and mesenchymal-like invasion, migration, colonization, and tumour formation properties [140].

Intriguingly, accumulating evidence supports the idea that non-CSCs can be induced into a transient, stem-like state enabling them to become drug-tolerant, involving reversible phenotypic switching through which EMT is also implicated. For instance, non-CSC cells in hepatocellular carcinoma exposed to carboplatin treatment acquired stem-like properties characterized by increased pluripotency marker expression (Sox2 and Oct3/4) and tumoursphere formation capacity [141]. Using both bladder and breast cancer cell lines model, $\mathrm{He}$ et al. demonstrated that cancer cells acquire a drug resistant, highly tumorigenic, cancer stem-like phenotype through modulation of the PI3K/Akt/ $\beta$-catenin/CBP pathway [142]. Goldman et al. demonstrated that exposure of human breast cancer explants and cancer cell lines to high dosage of taxanes induce phenotypic change towards $\mathrm{CD} 44^{\text {hi }} \mathrm{CD} 24^{\mathrm{hi}}$ [143]. This state transition conferring the cells with chemotherapy-tolerant properties is dependent on Src kinase signaling pathway and suppression of apoptosis [143]. In another study, drug-tolerant phenotypes are acquired transiently via engagement of IGF-1 receptor signaling and a high expression of epigenetic modifiers such as histone deacetylases (HDAC), and inhibition of either HDAC or IGFR disrupted CSC plasticity and re-sensitize the cells to drug treatment [144]. Taken together, the ability of cancer cells/CSC to transition between distinct cell states indicates the dynamics and the heterogeneity of an adaptive mechanism in response to cancer therapies.
Deregulation of cellular energetics have been implicated as one of the emerging hallmarks of cancer, as cancer cells intrinsically differed in their energy metabolism compared to the normal cells [145]. Until the recent years, many studies are emerging to elucidate the metabolic landscape in CSC, as metabolic reprogramming/switch may have a vital role in the acquisition of stemness, therefore conferring their resistance mechanisms. While CSCs also utilise aerobic glycolysis similar to cancer cells, studies have shown CSC switch their energy metabolism to an enhanced glycolytic via upregulation of GLUT1 transporters and resetting of their mitochondrial activity [146-149], similar to embryonic stem cells. This increase in glycolytic activity have been shown to increase the SP fractions with enhanced ABCG2 expression, mediated by ATP-mediated suppression of AMPK and activation of the Akt pathway [148]. Additionally, the ability to shift their metabolism is also profound even under different oxygen condition. Hypoxic or low oxygen condition have been implicated in inducing EMT, acquisition of stemness, resistance, promotes tumour aggression and induce metabolic switch [67]. Hypoxia-induced EMT enriching CSCs population is associated with increased expression of glycolytic genes, reduction in oxygen expenditures, reduced mitochondrial mass and membrane potential, and decreased production of ROS, with majority of the population residing in G1 phase of the cell cycle [149]. These show that metabolic reprogramming also plays important roles in regulating cellular fate in CSCs, which then contributes to their resistance properties. Metabolic reprogramming may represent an important intrinsic CSC regulation and glycolytic inhibition may be an attractive strategy to target the CSCs.

Taken together, resistance to therapeutic pressures such as chemotherapy present one of the main factors that contribute to tumour aggression by enriching the cells with stem-like characteristics, which is modulated via various adaptive mechanisms, summarized in Fig. 3.

\section{CSC in metastasis}

Metastasis is the development of secondary tumour growth at a distant organ or tissues from the primary tumour site, and is responsible for more than $90 \%$ cause of cancer related deaths [150]. Due to their resistant nature, CSCs are therefore inherently capable of metastasizing; this population known as metastatic CSC [150-152]. This section will provide insight into the roles of CSC in metastasis with a focus on the cellular and molecular mechanisms underlying the dissemination of metastatic CSCs.

Metastasis involves complex series of cellular and molecular events, characterised by local invasion, followed by intravasation into the blood and lymphatic system and then localisation and adaptation of disseminated cancer cells in the new metastatic site. However, what are the triggers for cancer cells to metastasise, and why do they go 


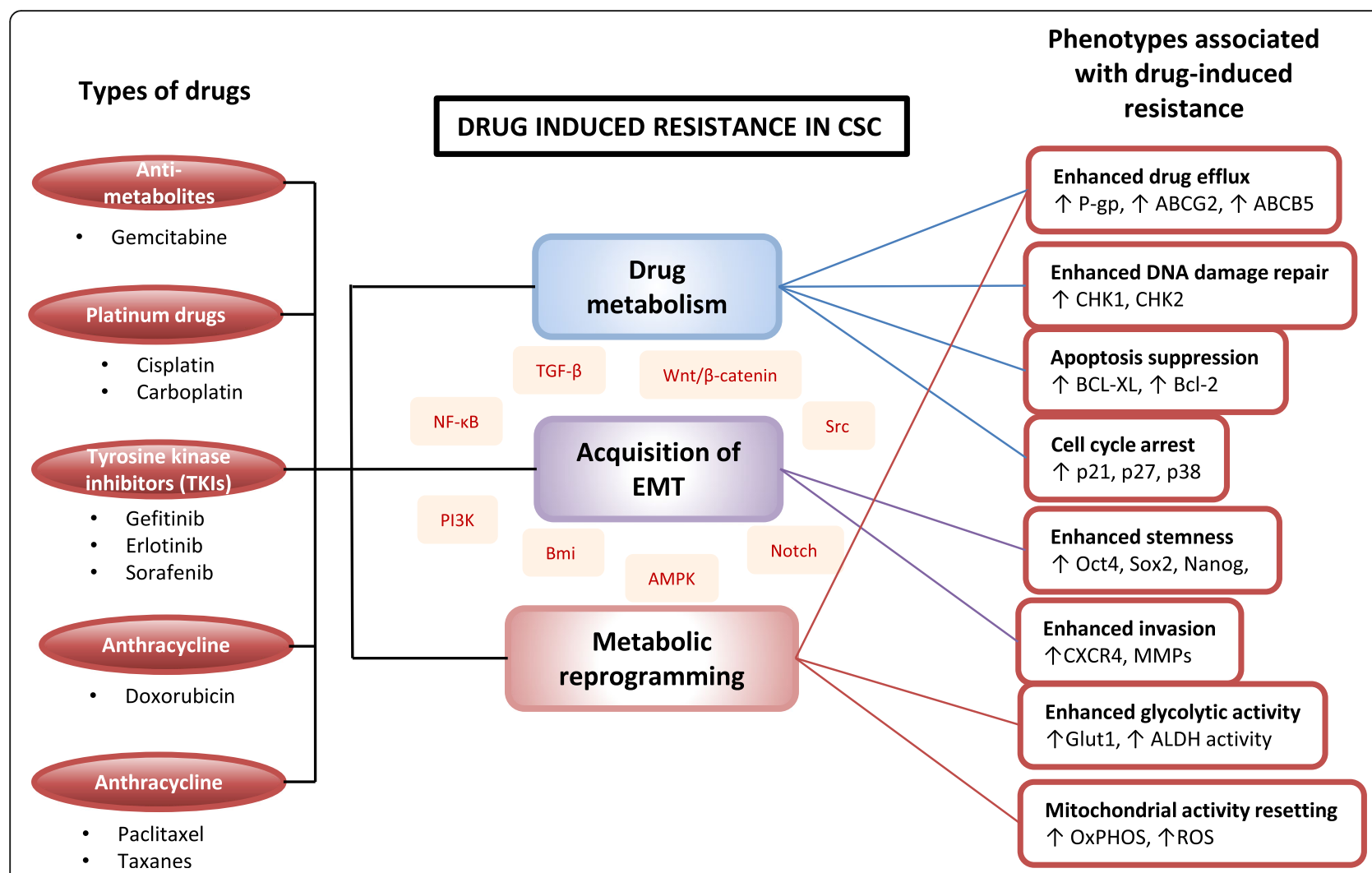

Fig. 3 Summary of key CSC-associated phenotypes via modulation of drug metabolism, acquisition of EMT and metabolic reprogramming involving signalling pathways regulation in response to different types of chemotherapeutics, conferring CSC the resistance properties

where they go? In 1989, the 'seed and soil' hypothesis for metastasis by Steven Paget's established pivotal framework whereby both the intrinsic properties of the cancer cells i.e. the 'seed' and receptive microenvironment i.e. the 'soil' is required for the successful engraftment at the distant tissue and form metastases [153, 154]. It has been demonstrated that metastatic capacity may be a pre-determined, intrinsic traits in the cancer cells during the earlier phase of cancer rendering them with survival advantage [155]. Molecular signatures of primary tumour predicting poor prognosis due to metastasis have been defined in many tumour types, suggesting metastatic gene signatures is a shared property among cancer cells in the primary tumours [156-159]. Indeed, stem-like gene expression signatures in primary tumour have been shown to correlate with metastatic and survival outcomes, suggesting that these metastatic cells may be of CSC origin. Riester et al. analysed mRNA expression data of histologically diverse cancer samples in comparison to gene expression in stem cell samples including human embryonic stem cells, human mesenchymal stem cells and CD34+ hematopoietic stem cells. The authors found that poor overall survival is correlated with gene expression signatures with the most similar expression to that of stem cells [160]. While it remains to be determined the extent of the overlap between these tissues specific metastatic program to the expression profile of CSCs, evidence have shown that metastatic cancer possess distinct stem-like gene expression signatures [161-163]. For instance, recent study by Lawson et al. found that early stage metastatic breast cancer cells possess distinct signatures, associated with increased expression stemness, EMT, pro-survival and dormancy signatures. Contrastingly, late stage metastatic cells exhibit genes signature more closely associated with that of primary tumour, with increase expression of differentiation markers and less stem-like [163]. In addition, transcriptional profiling shows that late stage metastatic prostate cancer shares a common signatures with prostate basal stem cells and is associated with invasiveness [164]. Taken together, these studies support the notion that metastasis is closely associated with the stem-like properties, suggesting important roles CSCs play in the metastasis process.

It has been demonstrated that CSCs play a role in the tumour microenvironment to orchestrate the metastasis cascade, via interactions with the cellular components of the tumour microenvironment to establish the new metastatic sites, termed the pre-metastatic niche for their arrival through a distinct cellular and molecular mechanisms $[165,166]$. Subsequently, similar to the primary tumour, the microenvironment in the metastatic 
sites promotes the dissemination of malignant cells by creating a growth supportive niche and promoting angiogenesis to support the growth of the secondary tumour. In the next sections, we highlight the possible roles of CSCs in the context of pre-metastatic initiation and the metastatic outgrowth, as summarised in Fig. 4.

\section{Establishment of pre-metastasis niche}

In the event of pre-metastatic niche establishment, cancer cells in the distant primary tumour sites hunt out new sites by secretion of factors and educating local cells including bone marrow derived hematopoietic progenitor cells (BMDCs), myeloid cells and endothelial cells, providing conducive foundation for their future seeding. It is known that VEGFR-1 expressing BMDCs are the key cellular components that are mobilized to site in the initiation of the pre-metastatic niche [167]. These cells express VLA$4(\alpha 4 \beta 1)$, which are recruited and mobilized by tumourderived secreted factors such as placental growth factors (PIGF) and VEGF-A to activate resident fibroblast in the metastasis niche to prime the metastatic site in lung rich with fibronectins [167]. In addition, inflammatory cells such as CD113b expressing myeloid cells and macrophages were also recruited leading to the formation pre-metastatic niche through increased expression of S100 calcium binding proteins following induction by TNF $\alpha$, TGF $\beta$ and VEGFA secreted by primary tumour cells $[168,169]$.

Exosomes are a class of tumour derived molecules of endocytic origin which are involved in the establishment of pre-metastatic niche Exosome are small, extracellular vesicles that carry diverse molecules, including proteins, lipids, RNA (mRNA, microRNA and other RNA molecules), as well as DNA molecules (dsDNA, ssDNA and mtDNA) [170]. Cancer cell-derived exosomes have been shown to have multiple roles in the events of metastasis, with a key role in the pre-metastatic niche formation through vascular remodelling and modulation of cellular behaviours in the pre-metastatic site (Fig. 4) [171]. For example, metastatic MDA-MB-231 breast cancer cells secrete exosomes enriched for miR-105 down-regulate tight junction zonula occludens 1 ( $\mathrm{ZO}-1$ ) protein expression, disrupting endothelial cell barrier and leads to increase vascular permeability, thus facilitate invasion and migration through intravasation [172]. Schilacci et al. demonstrate that exosomes derived from metastatic SW620 colon cancer cell line also enhance vascular permeability of surrounding endothelial cells via Rho/Rock pathway, in addition to promoting tumour progression

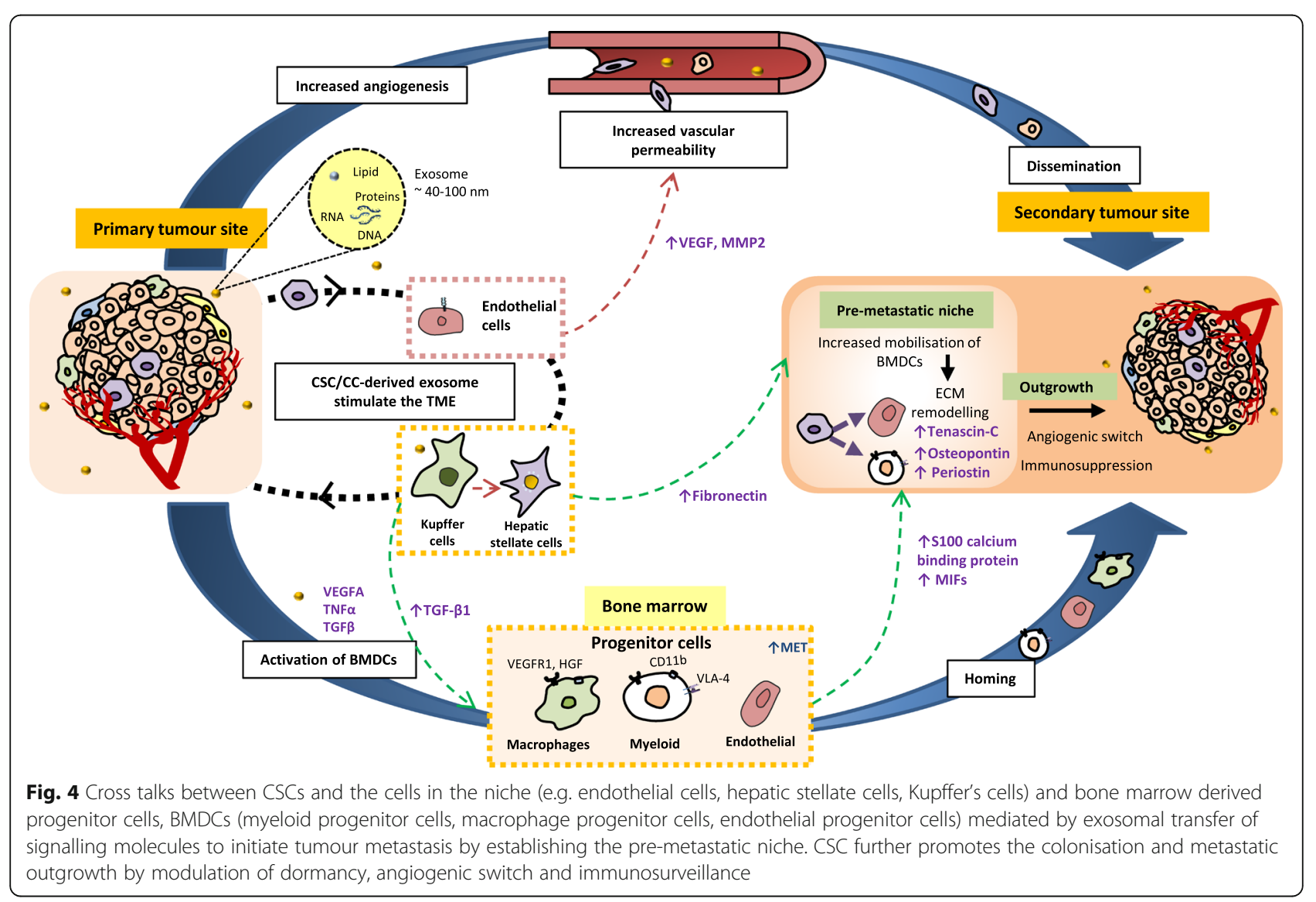


by inducing phenotypic switch in the less aggressive tumour cells to confer metastatic behaviours [173]. In view of the roles of CSCs in exosomes mediated metastasis, it was shown that exosomes released from CD105+ renal CSCs activate angiogenesis and promote lung metastasis in vivo via the uptake and parallel up-regulation of VEGF and MMP-2 in lung endothelial cells [174]. Exosomes derived from highly metastatic melanomas were shown to increase the metastatic capacity by 'educating' marrow hematopoietic progenitors to express the receptor tyrosine kinase MET, which were then activated by hepatocyte growth factor (HGF) rendering BMDCs with higher migratory potentials and capable of establishing pre-metastatic niches [175]. Similarly, exosomes derived from pancreatic ductal adenocarcinomas are highly expressed in migratory inhibitory factors (MIFs) induces fibrosis and subsequently liver metastasis through crosstalks with Kupffer cells and hepatic stellate cells [176]. While there are increasing studies on the significance of exosomes-mediated cellular communication between CSCs and the tumour microenvironment promotes cancer progression, still little evidence is available on roles of CSCderived exosomes implicated in regulation of metastasis.

\section{Colonisation and expansion of metastatic growth}

During colonisation of distant organ, cancer cells in the primary tumour site invade the surrounding stroma and enter the vasculature (i.e. intravasation) [177]. The capacity for invasion and migration of cancer cells at the primary tumour site during the intravasation is facilitated by the EMT program [150]. In response to growth factor such as TGF- $\beta 1$, activation of EMT allows the circulating tumour cells (CTCs) to translocate to distant site during metastasis, whereas mesenchymal-epithelial transition (MET) activation after extravasation may facilitate colonisation of the disseminated tumour cells (DTC) [178]. Increasing evidence in various cancer models suggests that a subpopulation of CTCs bears CSC phenotypes which intravasate and migrate together, suggesting the roles of CSCs during the initial metastasis process [179-183]. Indeed, the acquisition of the EMT phenotypes is also an important feature of CSCs which endow them with inherent metastatic potential [150]. Following the intravasation, CTCs transported via the blood stream to distant sites are arrested in the capillary bed, and subsequently extravasate through the microvascular walls to the parenchyma of the distant organ in which they may survive, proliferate and thereby establish metastatic colonies [184]. The successful sowing the newly DTC in the new 'soil' is influenced largely by the extrinsic factors i.e. of the microenvironment in addition to the cell-intrinsic factors, forming a metastatic niche that allows the survival and new tumour growth. The formation of metastatic niche constitutes adaptations and interactions of the seeding cells with the various niche associated cells, growth factors, soluble factors, inflammatory milieu, cytokine, enzymes, and ECM to facilitate the colonisation and metastatic outgrowth [165].

The adaptation period following dissemination is usually preceded by a period of dormancy in the DTC, which can last up to several decades [185]. Previous studies suggest that exit from the dormancy requires evasion from the immune surveillance mechanism that contributes to limit the outgrowth of micro-metastases and angiogenic switch to form micro-metastases, though the exact mechanism of DTC activation remains unclear [186-188]. Striking overlap exist between the behaviour of cancer cells in dormant state and behaviours of CSCs in tumour especially in the context of tumour outgrowth following metastasis dissemination, suggesting CSCs could be a subset of the dormant DTC $[189,190]$. The regulation of dormant state is governed by a combination of intracellular and extracellular signals within the tumour microenvironment involving regulation of quiescence, alteration in angiogenic response and modulation of immune surveillance [189]. In the context of regulation of quiescence, equilibrium between the activation of p38/MAPK and ERK/MAPK is the key signalling determinant [191]. Additionally TGF- $\beta$ and BMP signalling pathways, that regulate the maintenance of undifferentiated state in CSCs, also contribute to the maintenance of dormant state in tumour [192, 193]. For example, BMP7 secreted by bone stromal cells induced dormancy in prostate cancer stem-like cells [194]. BMP7 is also reported to induce CSC dormancy by activating p38/MAPK, p21, and $\mathrm{N}$-myc downstream-regulated gene 1 (NDRG1) in a BMP receptor 2 (BMPR2)-dependent manner [191]. Hedgehog signalling pathways that govern the self-renewal properties sustain the CSC quiescence and stemness via upregulation of Bmi protein $[195,196]$. Altogether, cancer dormancy that precedes the colonisation and metastatic outgrowth involves CSCs and development of therapeutic that manipulate this biology may be critical in halting the CSC-driven tumour recurrence. However, further studies are still needed to precisely elucidate the regulations of CSC dormancy in various cancer models, including their biology in different stages of cancer progression.

Angiogenesis induction represents a fundamental event underlying the switch from tumour dormancy to progressive cancer outgrowth. Bone marrow-derived endothelial progenitors cells (EPC) have been identified to be a critical cellular component that is recruited to mediate the angiogenic switch from micro- to macrometastasis and thus promotes metastatic outgrowth. [197]. The inhibitor of differentiation transcription factor, Id- 1 , which is a pro-angiogenic factors in primary tumour [198] is critical for the mobilization and recruitment of EPCs to micrometastases. Stankic et al. shows that Id-1 also promotes metastasis by inducing mesenchymal to epithelial transition (MET) through antagonism with transcription factor 
Twist in lung metastasis, and overexpression of Id-1 induced by TGF- $\beta$ generates breast cancer cells with CSClike properties [199]. In addition to EPCs, other cell types such as TAMs also stimulate angiogenesis by expression of VEGF and angiopoietins, promote recruitment of other inflammatory cells, and secrete proteases to facilitate matrix remodelling [200]. Subsequently, progression of the metastasis outgrowth is potentiated by the cellular and molecular component of the metastatic niche. For example, in breast cancer metastasis to the bone, osteoblasts secrete the inflammatory cytokine interleukin 6 (IL6) induced by Notch activation contributes to metastatic outgrowth. Metastatic breast cancer cells in the bone benefit from CXCL12 and IGF1 which, through PI3K signalling, promote survival in metastatic cancer cells in a Src dependent manner [201]. In addition, metastatic outgrowth in breast cancer and melanoma were also promoted by various microRNAs by inducing recruitment of endothelial cells and angiogenesis [202, 203]. Oskarsson et al. show that breast cancer cell derived-TNC promotes the survival and outgrowth of pulmonary micro-metastases. TNC also enhances stem cell associated signalling Wnt and Notch, implicating CSCs may modulate the metastatic niche through TNC expressions [103]. Osteopontin (OPN), a glycoprotein that negatively regulates the pool size of HSCs in bone marrow, is also critical for breast cancer bone metastasis [204]. The expression levels of OPN in tumour microenvironment are regulated by CSCs, and, in turn, OPN modulate CSC phenotype via binding with $\mathrm{CD} 44+$ cells in promoting tumour progression and metastasis [205]. Additionally, CSC may secrete OPN to recruit bone-marrow derived cells to hijack the niches for normal stem cells or recruit new components to form a permissive niche including immune surveillance. Periostin (POSTN), another matricellular proteins are secreted by stromal cells to prime the lung stroma for CSC-supportive niche in response to TGF- $\beta 3$ secretion by tumour cells [206]. POSTN recruits Wnt ligands (Wnt1 and Wnt3a), augmenting Wnt signalling in CSCs, which promotes CSC self-renewal and metastatic formation [206]. Taken together, these studies suggest CSCs promotes progression of metastasis growth by interacting with niche components to form permissive niche thus supporting their self-renewal.

\section{Future perspective: Challenges and opportunities}

Tumour progression involves a dynamic changes and complex interactions within the tumour microenvironment that contributes to the maintenance of CSC phenotypes including resistance properties. CSC-based therapeutic are under the area of intensive research by targeting the different mechanisms that sustain the stemness and resistance nature of CSCs, and with a number of these drugs entering the early phase of clinical trials [207] These mechanisms includes (i) targeting cell surface markers of CSCs, (ii) targeting CSC signalling pathways (iii) microRNA-based therapeutics, (iv) targeting the components of tumour microenvironment, (v) immunotherapy and (vi) targeting CSC metabolisms. Developments of therapeutics that specifically target CSCs remain a crucial endeavour for successful eradication of cancer and not without great challenges, owing to their heterogeneity and cellular plasticity contributed by the different factors in the microenvironment. While CSC-specific targeting represents an attractive strategy as it may totally abolish cancer from recurrence, further studies are warranted in investigating mechanisms involved in cancer resistance to therapy and to determine whether the cells responsible for cancer relapse are similar to CSCs that initially perpetuate the tumour or as a results of resistance acquisition. As CSCs collaborate with the tumour microenvironment to favour their survival and resistance to chemotherapy, these interactions are not only important to understand treatment outcome, but could also provide useful targets for therapy.

Nevertheless, as discussed in this review, it is critical to evaluate whether this resistance is the results of discrete entities of CSCs or non-CSCs that transitioned to a more stem-like states to escape therapies which involve multiple mechanisms contributing to more tumour heterogeneity. Thus, as we begin to unravel the complexity of the tumour progression driven as the function of CSCs as well as their interaction with the tumour microenvironment, it presents a critical tool for preclinical studies and the importance of using the right models that recapitulate the in vivo cancer progression. On the other hand, CSCs heterogeneity may be an opportunity in the area of personalized medicine, therefore the development of novel assays to predict human tumour response to therapy will be helpful to choose the most appropriate treatment, increasing our chance to treat cancer more successfully.

\section{Conclusion}

In this review we have summarised CSCs as a critical drivers of tumour progression, highlighting their behaviours and roles in the different stages of cancer which include tumour initiation, promotion and metastasis. Initiation of cancer by CSCs is prominent due to their stemness properties allowing them to accumulate the underlying carcinogenic and mutagenic inducer including inflammation and oxidative stress. CSC further promotes cancer growth and progression by mutual interaction with the microenvironment and harnesses them to favour their own survival, expansion, resistance properties, promotes angiogenesis and metastatic capability. Therefore, CSCs as potential therapeutic targets will be crucial in developing therapies that control cancer and to achieve more improved clinical responses in patients. Unlocking the biology of CSCs in the 
tumorigenesis and metastasis is key in the development of novel therapeutics for total elimination of CSCs thus improving the treatment modalities.

\section{Abbreviations}

ALDH: Aldehyde dehydrogenase; BMDCs: Bone marrow derived hematopoietic progenitor cells; CAFs: Cancer-associated fibroblasts; COX2: Cyclooxygenase-2; CSCs: Cancer stem cells; DCN: Decorin; DTC: Disseminated tumour cells; ECM: Extracellular matrix; EMT: Epithelial-mesenchymal transition; EPC: Endothelial progenitor cells; EV: Extracellular vehicles; FOXP2: Forkhead box protein P2; HDAC: Histone deacetylase; HGF: Hepatocyte growth factor; LGR5: Leucine-rich repeat-containing G protein-coupled receptor 5; LOX: Lysyl oxidase; LPPs: Lipid peroxidation products; LUM: Lumican; M-CSFs: Macrophage colony stimulating factor; MET: Mesenchymal to epithelial transition; MIFs: Migratory inhibitory factors; MMP: Matrix metalloproteinase; MSC: Mesenchymal stem cells; MSC-EVs: MSC-derived EVs; MSI1: Musashi homolog 1; NK cells: Natural killer cells; OPN: Osteopontin; POSTN: Periostin; RNS: Reactive nitrogen species; ROS: Reactive oxygen species; SDF-1: Stromal derived factors 1; SH: Schistosomahaematobium; SLRPs: Ssmall leucine-rich proteoglycans; SP: Side populations; TACs: Tumour associated cells; TAMs: Tumourassociate macrophage; TANs: Tumour-associate neutrophils; TNC: Tenascins C

\section{Acknowledgements}

The authors thank Prof. Dr. Fazlul Sarkar for valuable comments in the earlier stage of the manuscripts. We thank Stem Cell Laboratory Lab members: Yew Hong Wen and Agnes Ong Lee Chen for their feedbacks during the preparation of the figures in the manuscript.

\section{Funding}

This work is supported by the University of Malaya Research Grant (UMRG-RP032-14HTM).

\section{Availability of data and materials}

All data generated or analysed during this study are included in this article.

\section{Authors' contributions}

AZA and TSR drafted the manuscript. Both authors read and approved the final manuscript.

\section{Authors' information}

AZA (MSC.) is a Ph.D student in the Department of Molecular Medicine, Faculty of Medicine University of Malaya, under the supervision of TSR (Ph.D), Principal Investigator and Senior Lecturer in the Department of Molecular Medicine, Faculty of Medicine University of Malaya.

Ethics approval and consent to participate Not applicable.

\section{Consent for publication}

Not applicable.

\section{Competing interests}

The authors declare that they have no competing interests.

\section{Publisher's Note}

Springer Nature remains neutral with regard to jurisdictional claims in published maps and institutional affiliations.

\section{Received: 4 September 2017 Accepted: 1 March 2018} Published online: 06 March 2018

\section{References}

1. Reya T, Morrison SJ, Clarke MF, Weissman IL. Stem cells, cancer, and cancer stem cells. Nature. 2001;414:105-11.

2. Beck B, Blanpain C. Unravelling cancer stem cell potential. Nat Rev Cancer. 2013;13:727-38.

3. Weiswald LB, Bellet D, Dangles-Marie V. Spherical cancer models in tumor biology. Neoplasia. 2015;17:1-15.

4. Sell S. On the stem cell origin of cancer. Am J Pathol. 2010;176:2584-94.
5. Pisco AO, Huang S. Non-genetic cancer cell plasticity and therapy-induced stemness in tumour relapse: 'what does not kill me strengthens me'. Br J Cancer. 2015;112:1725-32.

6. Biddle A, Gammon L, Liang X, Costea DE, Mackenzie IC. Phenotypic plasticity determines cancer stem cell therapeutic resistance in oral squamous cell carcinoma. EBioMedicine. 2016;4:138-45.

7. Ye J, Wu D, Wu P, Chen Z, Huang J. The cancer stem cell niche: cross talk between cancer stem cells and their microenvironment. Tumour Biol. 2014; 35:3945-51.

8. Moolgavkar SH, Luebeck EG. Multistage carcinogenesis and the incidence of human cancer. Genes Chromosom Cancer. 2003;38:302-6.

9. Hatina J. The dynamics of cancer stem cells. Neoplasma. 2012;59:700-7.

10. Tysnes BB, Bjerkvig R. Cancer initiation and progression: involvement of stem cells and the microenvironment. Biochimica et Biophysica Acta (BBA)reviews on. Cancer. 2007;1775:283-97.

11. Lapidot T, Sirard C, Vormoor J, Murdoch B, Hoang T, Caceres-Cortes J, Minden M, Paterson B, Caligiuri MA, Dick JE. A cell initiating human acute myeloid leukaemia after transplantation into SCID mice. Nature. 1994;367:645-8.

12. Al-Haij M, Wicha MS, Benito-Hernandez A, Morrison SJ, Clarke MF. Prospective identification of tumorigenic breast cancer cells. Proc Natl Acad Sci. 2003;100:3983-8.

13. Singh SK, Hawkins C, Clarke ID, Squire JA, Bayani J, Hide T, Henkelman RM, Cusimano MD, Dirks PB. Identification of human brain tumour initiating cells. Nature. 2004;432:396-401.

14. Zhou BB, Zhang H, Damelin M, Geles KG, Grindley JC, Dirks PB. Tumourinitiating cells: challenges and opportunities for anticancer drug discovery. Nat Rev Drug Discov. 2009:8:806-23.

15. Boumahdi S, Driessens G, Lapouge G, Rorive S, Nassar D, Le Mercier M, Delatte B, Caauwe A, Lenglez S, Nkusi E. SOX2 controls tumour initiation and cancer stem-cell functions in squamous-cell carcinoma. Nature. 2014;511:246-50.

16. Demaria S, Pikarsky E, Karin M, Coussens LM, Chen Y-C, El-Omar EM, Trinchieri G, Dubinett SM, Mao JT, Szabo E. Cancer and inflammation: promise for biological therapy. J Immunother. 2010;33:335.

17. Lu H, Ouyang W, Huang C. Inflammation, a key event in cancer development. Mol Cancer Res. 2006;4:221-33.

18. Blaylock RL. Cancer microenvironment, inflammation and cancer stem cells: a hypothesis for a paradigm change and new targets in cancer control. Surg Neurol Int. 2015;6:92

19. Morales-Sánchez A, Fuentes-Pananá EM. Human viruses and cancer. Viruses. 2014:6:4047-79.

20. Ohnishi S, Ma N, Thanan R, Pinlaor S, Hammam O, Murata M, Kawanishi S. DNA damage in inflammation-related carcinogenesis and cancer stem cells. Oxidative Med Cell Longev. 2013;2013:9.

21. Okada F. Inflammation and free radicals in tumor development and progression. Redox Rep. 2002;7:357-68.

22. Ma N, Thanan R, Kobayashi H, Hammam O, Wishahi M, El Leithy T, Hiraku Y, Amro E-K, Oikawa S, Ohnishi S. Nitrative DNA damage and Oct3/4 expression in urinary bladder cancer with Schistosomahaematobium infection. Biochem Biophys Res Commun. 2011:414:344-9.

23. Thanan R, Murata M, Ma N, Hammam O, Wishahi M, El Leithy T, Hiraku Y, Oikawa $\mathrm{S}$, Kawanishi S. Nuclear localization of COX-2 in relation to the expression of stemness markers in urinary bladder cancer. Mediat Inflamm. 2012;2012:8.

24. Logan CM, Giordano A, Puca A, Cassone M. Prostaglandin E2: at the crossroads between stem cell development, inflammation and cancer. Cancer Biol Ther. 2007:6:1517-20.

25. Kawanishi S, Hiraku Y, Oikawa S. Mechanism of guanine-specific DNA damage by oxidative stress and its role in carcinogenesis and aging. Mut Res. 2001;488:65-76.

26. Thanan R, Pairojkul C, Pinlaor S, Khuntikeo N, Wongkham C, Sripa B, Ma N, Vaeteewoottacharn K, Furukawa A, Kobayashi H. Inflammation-related DNA damage and expression of CD133 and Oct3/4 in cholangiocarcinoma patients with poor prognosis. Free Radic Biol Med. 2013;65:1464-72.

27. Lau EY-T, Ho NP-Y, Lee TK-W. Cancer Stem Cells and Their Microenvironment: Biology and Therapeutic Implications. Stem Cells Int. 2017;2017:11.

28. Zhao J. Cancer stem cells and Chemoresistance: the smartest survives the raid. Pharmacol Ther. 2016;160:145-58.

29. Chen X, Liao R, Li D, Sun J. Induced cancer stem cells generated by radiochemotherapy and their therapeutic implications. Oncotarget. 2017;8: 17301-12.

30. Cabarcas SM, Mathews LA, Farrar WL. The cancer stem cell niche-there goes the neighborhood? Int I Cancer. 2011;129:2315-27. 
31. Lee G, Hall III RR, Ahmed AU. Cancer Stem Cells: Cellular Plasticity, Niche, and its Clinical Relevance. J Stem Cell Res Ther. 2016;6:363.

32. Quante M, Tu SP, Tomita H, Gonda T, Wang SS, Takashi S, Baik GH, Shibata W, Diprete B, Betz KS, Friedman R, Varro A, Tycko B, Wang TC. Bone marrow-derived myofibroblasts contribute to the mesenchymal stem cell niche and promote tumor growth. Cancer Cell. 2011;19:257-72.

33. Forsberg K, Valyi-Nagy I, Heldin C-H, Herlyn M, Westermark B. Platelet-derived growth factor (PDGF) in oncogenesis: development of a vascular connective tissue stroma in xenotransplanted human melanoma producing PDGF-BB. Proc Natl Acad Sci. 1993;90:393-7.

34. Giannoni E, Bianchini F, Masieri L, Serni S, Torre E, Calorini L, Chiarugi P. Reciprocal activation of prostate cancer cells and cancer-associated fibroblasts stimulates epithelial-mesenchymal transition and cancer stemness. Cancer Res. 2010;70:6945-56.

35. Hawinkels L, Paauwe M, Verspaget H, Wiercinska E, Van Der Zon J, Van Der Ploeg K, Koelink P, Lindeman J, Mesker W, Ten Dijke P. Interaction with colon cancer cells hyperactivates TGF- $\beta$ signaling in cancer-associated fibroblasts. Oncogene. 2014;33:97-107.

36. Strutz F, Zeisberg M, Hemmerlein B, Sattler B, Hummel K, Becker V, Müller GA. Basic fibroblast growth factor expression is increased in human renal fibrogenesis and may mediate autocrine fibroblast proliferation. Kidney Int. 2000;57:1521-38

37. Kalluri R. The biology and function of fibroblasts in cancer. Nat Rev Cancer 2016;16:582-98

38. Valenti G, Quinn HM, Heynen G, Lan L, Holland JD, Vogel R, WulfGoldenberg A, Birchmeier W. Cancer stem cells regulate cancer-associated fibroblasts via activation of hedgehog signaling in mammary gland tumors. Cancer Res. 2017;77:2134-47.

39. Vermeulen L, Felipe De Sousa EM, Van Der Heijden M, Cameron K, De Jong $J$ H, Borovski T, Tuynman JB, Todaro M, Merz C, Rodermond H. Wnt activity defines colon cancer stem cells and is regulated by the microenvironment. Nat Cell Biol. 2010;12:468-76.

40. Lau Eunice Yuen T, Lo J, Cheng Bowie Yik L, Ma Mark Kin F, Lee Joyce Man F, Ng Johnson Kai Y, Chai S, Lin Chi H, Tsang Suk Y, Ma S, Ng Irene Oi L, Lee Terence Kin W. Cancer-associated fibroblasts regulate tumor-initiating cell plasticity in hepatocellular carcinoma through c-met/FRA1/HEY1 signaling. Cell Rep. 2016;15:1175-89.

41. Soon PSH, Kim E, Pon CK, Gill AJ, Moore K, Spillane AJ, Benn DE, Baxter RC Breast cancer-associated fibroblasts induce epithelial-to-mesenchymal transition in breast cancer cells. Endocr Relat Cancer. 2013;20:1-12.

42. Yu Y, Xiao C, Tan L, Wang Q, Li X, Feng Y. Cancer-associated fibroblasts induce epithelial-mesenchymal transition of breast cancer cells through paracrine TGF- $\beta$ signalling. Br J Cancer. 2014;110:724.

43. Nishimura K, Semba S, Aoyagi K, Sasaki H, Yokozaki H. Mesenchymal stem cells provide an advantageous tumor microenvironment for the restoration of cancer stem cells. Pathobiology. 2012;79:290-306.

44. Davis H, Irshad S, Bansal M, Rafferty H, Boitsova T, Bardella C, Jaeger E, Lewis A, Freeman-Mills L, Giner FC, Rodenas-Cuadrado P, Mallappa S, Clark S, Thomas H, Jeffery R, Poulsom R, Rodriguez-Justo M, Novelli M, Chetty R, Silver A, Sansom OJ, Greten FR, Wang LM, East JE, Tomlinson I, Leedham SJ. Aberrant epithelial GREM1 expression initiates colonic tumorigenesis from cells outside the stem cell niche. Nat Med. 2014;21:62-70.

45. Cuiffo BG, Campagne A, Bell GW, Lembo A, Orso F, Lien EC, Bhasin MK, Raimo M, Hanson SE, Marusyk A, El-Ashry D, Hematti P, Polyak K, MechtaGrigoriou F, Mariani O, Volinia S, Vincent-Salomon A, Taverna D, Karnoub AE. MSC-regulated microRNAs converge on the transcription factor FOXP2 and promote breast cancer metastasis. Cell Stem Cell. 2014;15:762-74.

46. Houthuijzen J, Daenen L, Roodhart J, Voest E. The role of mesenchymal stem cells in anti-cancer drug resistance and tumour progression. $\mathrm{Br} J$ Cancer. 2012;106:1901-6.

47. Lopatina T, Gai C, Deregibus MC, Kholia S, Camussi G. Cross talk between cancer and mesenchymal stem cells through extracellular vesicles carrying nucleic acids. Front Oncol. 2016;6:125

48. Bliss SA, Sinha G, Sandiford OA, Williams LM, Engelberth DJ, Guiro K, Isenalumhe LL, Greco SJ, Ayer S, Bryan M, Kumar R, Ponzio NM, Rameshwar P. Mesenchymal stem cell-derived exosomes stimulate cycling quiescence and early breast cancer dormancy in bone marrow. Cancer Res. 2016;76:5832-44.

49. Vallabhaneni KC, Penfornis P, Dhule S, Guillonneau F, Adams KV, Mo YY, Xu R, Liu Y, Watabe K, Vemuri MC, Pochampally R. Extracellular vesicles from bone marrow mesenchymal stem/stromal cells transport tumor regulatory microRNA, proteins, and metabolites. Oncotarget. 2015;6:4953-67.
50. Bruno S, Collino F, Deregibus MC, Grange C, Tetta C, Camussi G. Microvesicles derived from human bone marrow mesenchymal stem cells inhibit tumor growth. Stem Cells Dev. 2012;22:758-71.

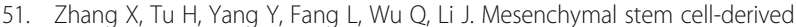
extracellular vesicles: roles in tumor growth, progression, and drug resistance. Stem Cells Int. 2017;2017:12.

52. Du T, Ju G, Wu S, Cheng Z, Cheng J, Zou X, Zhang G, Miao S, Liu G, Zhu Y. Microvesicles derived from human Wharton's jelly mesenchymal stem cells promote human renal cancer cell growth and aggressiveness through induction of hepatocyte growth factor. PLoS One. 2014;9:e96836.

53. Li T, Zhang C, Ding Y, Zhai W, Liu K, Bu F, Tu T, Sun L, Zhu W, Zhou F. Umbilical cord-derived mesenchymal stem cells promote proliferation and migration in MCF-7 and MDA-MB-231 breast cancer cells through activation of the ERK pathway. Oncol Rep. 2015;34:1469-77.

54. Wang W, Zhong W, Yuan J, Yan C, Hu S, Tong Y, Mao Y, Hu T, Zhang B, Song $\mathrm{G}$. Involvement of $\mathrm{Wnt} / \beta$-catenin signaling in the mesenchymal stem cells promote metastatic growth and chemoresistance of cholangiocarcinoma. Oncotarget. 2015;6:42276.

55. Kitamura T, Qian BZ, Pollard JW. Immune cell promotion of metastasis. Nat Rev Immunol. 2015;15:73-86.

56. Raggi C, Correnti M, Sica A, Andersen JB, Cardinale V, Alvaro D, Chiorino G, Forti E, Glaser S, Alpini G. Cholangiocarcinoma stem-like subset shapes tumor-initiating niche by educating associated macrophages. J Hepatol. 2017;66:102-15.

57. Zhou W, Susan QK, Zhi H, William F, Xiaoguang F, Jeremy P, Ling W, Andrew ES, Roger EM, Xiaoxia L, Jeremy NR, Shideng. Periostin secreted by glioblastoma stem cells recruits M2 tumour-associated macrophages and promotes malignant growth. Nat Cell Biol. 2015;17:170-82.

58. Ostuni R, Kratochvill F, Murray PJ, Natoli G. Macrophages and cancer: from mechanisms to therapeutic implications. Trends Immunol. 2015;36:229-39.

59. Williams CB, Yeh ES, Soloff AC. Tumor-associated macrophages: unwitting accomplices in breast cancer malignancy. NPJ Breast Cancer. 2016;2:15025.

60. Su MJ, Aldawsari H, Amiji M. Pancreatic cancer cell exosome-mediated macrophage reprogramming and the role of MicroRNAs 155 and 125b2 transfection using nanoparticle delivery systems. Sci Rep. 2016;6:30110.

61. Braicu C, Tomuleasa C, Monroig P, Cucuianu A, Berindan-Neagoe I, Calin GA. Exosomes as divine messengers: are they the Hermes of modern molecular oncology? Cell Death Differ. 2014;22:34.

62. Zheng P, Chen L, Yuan X, Luo Q, Liu Y, Xie G, Ma Y, Shen L. Exosomal transfer of tumor-associated macrophage-derived miR-21 confers cisplatin resistance in gastric cancer cells. J Exp Clin Cancer Res. 2017;36:53.

63. Semenza GL. Oxygen sensing, hypoxia-inducible factors, and disease pathophysiology. Ann Rev Pathol. 2014;9:47-71.

64. Semenza GL. The hypoxic tumor microenvironment: a driving force for breast cancer progression. Biochimica et Biophysica Acta (BBA)-molecular. Cell Res. 2016;1863:382-91.

65. Höckel M, Vorndran B, Schlenger K, Baußmann E, Knapstein PG. Tumor oxygenation: a new predictive parameter in locally advanced cancer of the uterine cervix. Gynecol Oncol. 1993;51:141-9.

66. Brizel DM, Scully SP, Harrelson JM, Layfield LJ, Bean JM, Prosnitz LR, Dewhirst MW. Tumor oxygenation predicts for the likelihood of distant metastases in human soft tissue sarcoma. Cancer Res. 1996;56:941-3.

67. Carnero A, Lleonart M. The hypoxic microenvironment: a determinant of cancer stem cell evolution. Inside Cell. 2016;1:96-105.

68. Bennewith $\mathrm{KL}$, Durand RE. Quantifying transient hypoxia in human tumor xenografts by flow cytometry. Cancer Res. 2004;64:6183-9.

69. Brurberg KG, Thuen M, Ruud E-BM, Rofstad EK. Fluctuations in $\mathrm{p} \mathrm{O} 2$ in irradiated human melanoma xenografts. Radiat Res. 2006;165:16-25.

70. Azuma T, Yao S, Zhu G, Flies AS, Flies SJ, Chen L. B7-H1 is a ubiquitous antiapoptotic receptor on cancer cells. Blood. 2008;111:3635-43.

71. Li Z, Rich JN, Hypoxia and hypoxia inducible factors in cancer stem cell maintenance, in Diverse Effects of Hypoxia on Tumor Progression. Berlin, Heidelberg: Springer; 2010. p. 21-30.

72. Anido J, Sáez-Borderías A, Gonzàlez-Juncà A, Rodón L, Folch G, Carmona MA, Prieto-Sánchez RM, Barba I, Martínez-Sáez E, Prudkin L. TGF- $\beta$ receptor inhibitors target the CD44 high/ld1 high glioma-initiating cell population in human glioblastoma. Cancer Cell. 2010;18:655-68.

73. Scheel C, Eaton EN, Li SH-J, Chaffer CL, Reinhardt F, Kah K-J, Bell G, Guo W, Rubin J, Richardson AL. Paracrine and autocrine signals induce and maintain mesenchymal and stem cell states in the breast. Cell. 2011;145:926-40.

74. Scheel C, Weinberg RA. Phenotypic plasticity and epithelial-mesenchymal transitions in cancer and normal stem cells? Int J Cancer. 2011;129:2310-4. 
75. Krishnamachary B, Zagzag D, Nagasawa H, Rainey K, Okuyama H, Baek JH, Semenza GL. Hypoxia-inducible factor-1-dependent repression of E-cadherin in von Hippel-Lindau tumor suppressor-null renal cell carcinoma mediated by TCF3, ZFHX1A, and ZFHX1B. Cancer Res. 2006;66:2725-31.

76. Moreno-Bueno G, Portillo F, Cano A. Transcriptional regulation of cell polarity in EMT and cancer. Oncogene. 2008;27:6958-69.

77. Liu X, He L, Stensaas L, Dinger B, Fidone S. Adaptation to chronic hypoxia involves immune cell invasion and increased expression of inflammatory cytokines in rat carotid body. Am J Phys Lung Cell Mol Phys. 2009;296:L158-L66.

78. Liu F, Liu Y, Lui VC, Lamb JR, Tam PK, Chen Y. Hypoxia modulates lipopolysaccharide induced TNF-a expression in murine macrophages. Exp Cell Res. 2008;314:1327-36.

79. Pavlides S, Tsirigos A, Vera I, Flomenberg N, Frank PG, Casimiro MC, Wang C, Fortina P, Addya S, Pestell RG. Loss of stromal caveolin-1 leads to oxidative stress, mimics hypoxia and drives inflammation in the tumor microenvironment, conferring the "reverse Warburg effect": a transcriptional informatics analysis with validation. Cell Cycle. 2010;9:2201-19.

80. Kitamura T, Qian B-Z, Soong D, Cassetta L, Noy R, Sugano G, et al. CCL2induced chemokine cascade promotes breast cancer metastasis by enhancing retention of metastasis-associated macrophages. J Exp Med. 2015;212:1043.

81. Butler JM, Kobayashi H, Rafii S. Instructive role of the vascular niche in promoting tumour growth and tissue repair by angiocrine factors. Nat Rev Cancer. 2010;10:138-46.

82. Campos MS, Neiva KG, Meyers KA, Krishnamurthy S, Nor JE. Endothelial derived factors inhibit anoikis of head and neck cancer stem cells. Oral Oncol. 2011;48:26-32.

83. Liang Z, Brooks J, Willard M, Liang K, Yoon Y, Kang S, Shim H. CXCR4/ CXCL12 axis promotes VEGF-mediated tumor angiogenesis through Akt signaling pathway. Biochem Biophys Res Commun. 2007;359:716-22.

84. Galan-Moya EM, Le Guelte A, Lima Fernandes E, Thirant C, Dwyer J, Bidere N, Couraud PO, Scott MG, Junier MP, Chneiweiss H, Gavard J. Secreted factors from brain endothelial cells maintain glioblastoma stem-like cell expansion through the mTOR pathway. EMBO Rep. 2011;12:470-6.

85. Lu J, Ye X, Fan F, Xia L, Bhattacharya R, Bellister S, Tozzi F, Sceusi E, Zhou Y Tachibana I, Maru DM, Hawke DH, Rak J, Mani SA, Zweidler-McKay P, Ellis LM. Endothelial cells promote the colorectal cancer stem cell phenotype through a soluble form of Jagged-1. Cancer Cell. 2013;23:171-85.

86. Yan GN, Yang L, Lv YF, Shi Y, Shen LL, Yao XH, Guo QN, Zhang P, Cui YH, Zhang $X$. Endothelial cells promote stem-like phenotype of glioma cells through activating the hedgehog pathway. J Pathol. 2014;234:11-22.

87. Sun L, Pan J, Yu L, Liu H, Shu X, Sun L, Lou J, Yang Z, Ran Y. Tumor endothelial cells promote metastasis and cancer stem cell-like phenotype through elevated Epiregulin in esophageal cancer. Am J Cancer Res. 2016:6:2277-88.

88. Krishnamurthy S, Warner KA, Dong Z, Imai A, Nor C, Ward BB, Helman J, Taichman RS, Bellile EL, McCauley LK, Polverini PJ, Prince ME, Wicha MS, Nor JE. Endothelial interleukin- 6 defines the tumorigenic potential of primary human cancer stem cells. Stem Cells. 2014;32:2845-57.

89. Xu J, Zhang C, He Y, Wu H, Wang Z, Song W, Li W, He W, Cai S, Zhan W. Lymphatic endothelial cell-secreted CXCL1 stimulates lymphangiogenesis and metastasis of gastric cancer. Int J Cancer. 2012;130:787-97.

90. Johnson LA, Jackson DG. Inflammation-induced secretion of CCL21 in lymphatic endothelium is a key regulator of integrin-mediated dendritic cell transmigration. Int Immunol. 2010;22:839-49.

91. Heusschen R, van Gink M, Griffioen AW, Thijssen VL. MicroRNAs in the tumor endothelium: novel controls on the angioregulatory switchboard. Biochim Biophys Acta. 2010;1805:87-96.

92. Sigurdsson V, Hilmarsdottir B, Sigmundsdottir $H$, Fridriksdottir AJ, Ringner $M$, Villadsen R, Borg A, Agnarsson BA, Petersen OW, Magnusson MK, Gudjonsson T. Endothelial induced EMT in breast epithelial cells with stem cell properties. PLoS One. 2011;6:e23833.

93. Guo J, Liu C, Zhou X, Xu X, Deng L, Li X, et al. Conditioned Medium from Malignant Breast Cancer Cells Induces an EMT-Like Phenotype and an Altered N-Glycan Profile in Normal Epithelial MCF10A Cells. Int J Mol Sci. 2017;18:1528.

94. Folkins C, Shaked Y, Man S, Tang T, Lee CR, Zhu Z, Hoffman RM, Kerbel RS. Glioma tumor stem-like cells promote tumor angiogenesis and vasculogenesis via vascular endothelial growth factor and stromal-derived factor 1. Cancer Res. 2009;69:7243-51.

95. Bussolati B, Grange C, Sapino A, Camussi G. Endothelial cell differentiation of human breast tumour stem/progenitor cells. J Cell Mol Med. 2009;13:309-19.
96. Ricci-Vitiani L, Pallini R, Biffoni M, Todaro M, Invernici G, Cenci T, Maira G, Parati EA, Stassi G, Larocca LM. Tumour vascularization via endothelial differentiation of glioblastoma stem-like cells. Nature. 2010;468:824-8.

97. Wang R, Chadalavada K, Wilshire J, Kowalik U, Hovinga KE, Geber A, Fligelman B, Leversha M, Brennan C, Tabar V. Glioblastoma stem-like cells give rise to tumour endothelium. Nature. 2010;468:829-33.

98. Soda Y, Marumoto T, Friedmann-Monvinski D, Soda M, Liu F, Michiue H, Pastorino S, Yang M, Hoffman RM, Kesari S. Transdifferentiation of glioblastoma cells into vascular endothelial cells. Proc Natl Acad Sci. 2011;108:4274-80.

99. Lu P, Weaver VM, Werb Z. The extracellular matrix: a dynamic niche in cancer progression. J Cell Biol. 2012;196:395-406.

100. Novak K. Measuring the matrix. Nat Rev Cancer. 2003;3:394-5.

101. Rupp T, Langlois B, Koczorowska MM, Radwanska A, Sun Z, Hussenet T, Lefebvre O, Murdamoothoo D, Arnold C, Klein A. Tenascin-C orchestrates glioblastoma angiogenesis by modulation of pro-and anti-angiogenic signaling. Cell Rep. 2016;17:2607-19.

102. Xia S, Lal B, Tung B, Wang S, Goodwin CR, Laterra J. Tumor microenvironment tenascin- $C$ promotes glioblastoma invasion and negatively regulates tumor proliferation. Neuro-Oncology. 2015;18:507-17.

103. Oskarsson T, Acharyya S, Zhang XH, Vanharanta S, Tavazoie SF, Morris PG, Downey RJ, Manova-Todorova K, Brogi E, Massague J. Breast cancer cells produce tenascin $\mathrm{C}$ as a metastatic niche component to colonize the lungs. Nat Med. 2011;17:867-74.

104. Chiquet-Ehrismann R, Orend G, Chiquet M, Tucker RP, Midwood KS. Tenascins in stem cell niches. Matrix Biol. 2014;37:112-23.

105. Nie S, Gurrea M, Zhu J, Thakolwiboon S, Heth JA, Muraszko KM, Fan X, Lubman DM. Tenascin-C: a novel candidate marker for cancer stem cells in glioblastoma identified by tissue microarrays. J Proteome Res. 2015;14:814-22.

106. Fukunaga-Kalabis M, Martinez G, Nguyen T-TK, Kim D, Santiago-Walker A Roesch A, Herlyn M. Tenascin-C promotes melanoma progression by maintaining the ABCB5-positive side population. Oncogene. 2010;29:6115.

107. Jachetti E, Caputo S, Mazzoleni S, Brambillasca CS, Parigi SM, Grioni M, Piras IS, Restuccia U, Calcinotto A, Freschi M, Bachi A, Galli R, Bellone M. TenascinC protects cancer stem-like cells from immune surveillance by arresting Tcell activation. Cancer Res. 2015;75:2095-108.

108. Farace C, Oliver JA, Melguizo C, Alvarez P, Bandiera P, Rama AR, Malaguarnera G, Ortiz R, Madeddu R, Prados J. Microenvironmental modulation of Decorin and Lumican in Temozolomide-resistant glioblastoma and neuroblastoma cancer stem-like cells. PLoS One. 2015;10:e0134111.

109. Bhowmick NA, Neilson EG, Moses HL. Stromal fibroblasts in cancer initiation and progression. Nature. 2004;432:332-7.

110. Orimo A, Gupta PB, Sgroi DC, Arenzana-Seisdedos F, Delaunay T, Naeem R, Carey VJ, Richardson AL, Weinberg RA. Stromal fibroblasts present in invasive human breast carcinomas promote tumor growth and angiogenesis through elevated SDF-1/CXCL12 secretion. Cell. 2005;121:335-48.

111. Levental KR, Yu H, Kass L, Lakins JN, Egeblad M, Erler JT, Fong SF, Csiszar K, Giaccia A, Weninger W, Yamauchi M, Gasser DL, Weaver VM. Matrix crosslinking forces tumor progression by enhancing integrin signaling. Cell. 2009;139:891-906.

112. Lopez Jl, Kang I, You WK, McDonald DM, Weaver VM. In situ force mapping of mammary gland transformation. Integr Biol (Camb). 2011;3:910-21.

113. Dean M, Fojo T, Bates $S$. Tumour stem cells and drug resistance. Nat Rev Cancer. 2005;5:275-84.

114. Dylla SJ, Beviglia L, Park IK, Chartier C, Raval J, Ngan L, Pickell K, Aguilar J, Lazetic S, Smith-Berdan S, Clarke MF, Hoey T, Lewicki J, Gurney AL. Colorectal cancer stem cells are enriched in xenogeneic tumors following chemotherapy. PLoS One. 2008;3:e2428.

115. Abubaker K, Latifi A, Luwor R, Nazaretian S, Zhu H, Quinn MA, Thompson EW, Findlay JK, Ahmed N. Short-term single treatment of chemotherapy results in the enrichment of ovarian cancer stem cell-like cells leading to an increased tumor burden. Mol Cancer. 2013;12:24.

116. Taylor ST, Hickman JA, Dive C. Epigenetic determinants of resistance to etoposide regulation of $\mathrm{BCl}-\mathrm{XL}$ and Bax by tumor microenvironmental factors. J Natl Cancer Inst. 2000;92:18-23.

117. Maier S, Dahlstroem C, Haefliger C, Plum A, Piepenbrock C. Identifying DNA methylation biomarkers of cancer drug response. Am J Pharmacogenomics. 2005;5:223-32.

118. Dean M. ABC transporters, drug resistance, and cancer stem cells. J Mammary Gland Biol Neoplasia. 2009;14:3-9.

119. An Y, Ongkeko WM. ABCG2: the key to chemoresistance in cancer stem cells? Expert Opin Drug Metab Toxicol. 2009;5:1529-42. 
120. Xu F, Wang F, Yang T, Sheng Y, Zhong T, Chen Y. Differential drug resistance acquisition to doxorubicin and paclitaxel in breast cancer cells. Cancer Cell Int. 2014;14:538.

121. Xu X, Chai S, Wang P, Zhang C, Yang Y, Yang Y, Wang K. Aldehyde dehydrogenases and cancer stem cells. Cancer Lett. 2015;369:50-7.

122. Wang YH, Scadden DT. Harnessing the apoptotic programs in cancer stemlike cells. EMBO Rep. 2015;16:1084-98.

123. Bao S, Wu Q, McLendon RE, Hao Y, Shi Q, Hjelmeland AB, Dewhirst MW, Bigner $\mathrm{DD}$, Rich JN. Glioma stem cells promote radioresistance by preferential activation of the DNA damage response. Nature. 2006;444:756-60.

124. Ramasamy TS, Ayob AZ, Myint HHL, Thiagarajah S, Amini F. Targeting colorectal cancer stem cells using curcumin and curcumin analogues: insights into the mechanism of the therapeutic efficacy. Cancer Cell Int. 2015;15:96.

125. Todaro M, Francipane MG, Medema JP, Stassi G. Colon cancer stem cells: promise of targeted therapy. Gastroenterology. 2010;138:2151-62.

126. Cheung TH, Rando TA. Molecular regulation of stem cell quiescence. Nat Rev Mol Cell Biol. 2013;14:329-40.

127. Pece S, Tosoni D, Confalonieri S, Mazzarol G, Vecchi M, Ronzoni S, Bernard L, Viale G, Pelicci PG, Di Fiore PP. Biological and molecular heterogeneity of breast cancers correlates with their cancer stem cell content. Cell. 2010;140:62-73.

128. Haraguchi N, Ishii H, Mimori K, Tanaka F, Ohkuma M, Kim HM, Akita H, Takiuchi D, Hatano H, Nagano H. CD13 is a therapeutic target in human liver cancer stem cells. J Clin Invest. 2010;120:3326.

129. Deleyrolle LP, Harding A, Cato K, Siebzehnrubl FA, Rahman M, Azari H, Olson S, Gabrielli B, Osborne G, Vescovi A. Evidence for label-retaining tumour-initiating cells in human glioblastoma. Brain. 2011;134:1331-43.

130. Ishii A, Kimura T, Sadahiro H, Kawano H, Takubo K, Suzuki M, Ikeda E. Histological characterization of the tumorigenic "Peri-necrotic niche" harboring quiescent stem-like tumor cells in glioblastoma. PLoS One. 2016;11:e0147366.

131. Zeuner A. The secret life of quiescent cancer stem cells. Mol Cell Oncol. 2015;2:e968067.

132. Gao M, Choi Y, Kang S, Youn J, Cho N. CD24+ cells from hierarchically organized ovarian cancer are enriched in cancer stem cells. Oncogene. 2010;29:2672-80.

133. Wu M, Fernandez N, Celebre A, Srikanth M, Kessler J, Karamchandani J, Das S. SC-35BMP signaling regulates a quiescent cancer stem cell phenotype responsible for treatment resistance in glioblastoma. Neuro Oncol. 2014;16:v204.

134. Wang H, Zhang G, Zhang H, Zhang F, Zhou B, Ning F, Wang HS, Cai SH, Du J. Acquisition of epithelial-mesenchymal transition phenotype and cancer stem cell-like properties in cisplatin-resistant lung cancer cells through AKT/ beta-catenin/snail signaling pathway. Eur J Pharmacol. 2013:723:156-66.

135. Maseki S, ljichi K, Tanaka H, Fujii M, Hasegawa Y, Ogawa T, Murakami S, Kondo E, Nakanishi H. Acquisition of EMT phenotype in the gefitinib-resistant cells of a head and neck squamous cell carcinoma cell line through Akt/GSK-3beta/snail signalling pathway. Br J Cancer. 2012;106:1196-204.

136. Gomez-Casal R, Bhattacharya C, Ganesh N, Bailey L, Basse P, Gibson M, Epperly M, Levina V. Non-small cell lung cancer cells survived ionizing radiation treatment display cancer stem cell and epithelial-mesenchymal transition phenotypes. Mol Cancer. 2013;12:94.

137. Tu C-C, Cheng L-H, Hsu H-H, Chen L-M, Lin Y-M, Chen M-C, Lee N-H, Tsal F-J, Huang C-Y, Wu W-J. Activation of snail and EMT-like signaling via the IKKaß/NF-KB pathway in Apicidin-resistant HA22T hepatocellular carcinoma cells. Chin J Physiol. 2013;56:326-33.

138. Li J, Liu H, Yu J, Yu H. Chemoresistance to doxorubicin induces epithelialmesenchymal transition via upregulation of transforming growth factor $\beta$ signaling in HCT116 colon cancer cells. Mol Med Rep. 2015;12:192-8.

139. Wang Z, Li Y, Kong D, Banerjee S, Ahmad A, Azmi AS, Ali S, Abbruzzese JL, Gallick GE, Sarkar FH. Acquisition of epithelial-mesenchymal transition phenotype of gemcitabine-resistant pancreatic cancer cells is linked with activation of the notch signaling pathway. Cancer Res. 2009;69:2400-7.

140. Lee HH, Bellat V, Law B. Chemotherapy induces adaptive drug resistance and metastatic potentials via phenotypic CXCR4-expressing cell state transition in ovarian cancer. PLoS One. 2017:12:e0171044.

141. Hu X, Ghisolfi L, Keates AC, Zhang J, Xiang S, Lee DK, Li CJ. Induction of cancer cell stemness by chemotherapy. Cell Cycle. 2012;11:2691-8.

142. He K, Xu T, Xu Y, Ring A, Kahn M, Goldkorn A. Cancer cells acquire a drug resistant, highly tumorigenic, cancer stem-like phenotype through modulation of the PI3K/Akt/beta-catenin/CBP pathway. Int J Cancer. 2013;134:43-54.

143. Goldman A, Majumder B, Dhawan A, Ravi S, Goldman D, Kohandel M, Majumder PK, Sengupta S. Temporally sequenced anticancer drugs overcome adaptive resistance by targeting a vulnerable chemotherapyinduced phenotypic transition. Nat Commun. 2015;11:6139.
144. Sharma SV, Lee DY, Li B, Quinlan MP, Takahashi F, Maheswaran S, McDermott U, Azizian N, Zou L, Fischbach MA, Wong KK, Brandstetter K, Wittner B, Ramaswamy S, Classon M, Settleman J. A chromatinmediated reversible drug-tolerant state in cancer cell subpopulations. Cell. 2010;141:69-80.

145. Hanahan D, Weinberg RA. Hallmarks of cancer: the next generation. Cell. 2011;144:646-74.

146. Aguilar E, Marin de Mas I, Zodda E, Marin S, Morrish F, Selivanov V, MecaCortés Ó, Delowar H, Pons M, Izquierdo I. Metabolic reprogramming and dependencies associated with epithelial cancer stem cells independent of the epithelial-mesenchymal transition program. Stem Cells. 2016:34:1163-76.

147. Palorini R, Votta G, Balestrieri C, Monestiroli A, Olivieri S, Vento R, Chiaradonna F. Energy metabolism characterization of a novel cancer stem cell-like line 3AB-OS. J Cell Biochem. 2014;115:368-79.

148. Liu P, Liao J, Tang Z, Wu W, Yang J, Zeng Z, Hu Y, Wang P, Ju H, Xu R. Metabolic regulation of cancer cell side population by glucose through activation of the Akt pathway. Cell Death Differ. 2014;21:124-35.

149. Gammon L, Biddle A, Heywood HK, Johannessen AC, Mackenzie IC. Sub-sets of cancer stem cells differ intrinsically in their patterns of oxygen metabolism. PLoS One. 2013;8:e62493.

150. Li F, Tiede B, Massague J, Kang Y. Beyond tumorigenesis: cancer stem cells in metastasis. Cell Res. 2006;17:3-14.

151. Pang R, Law WL, Chu AC, Poon JT, Lam CS, Chow AK, Ng L, Cheung LW, Lan XR, Lan HY, Tan VP, Yau TC, Poon RT, Wong BC. A subpopulation of CD26+ cancer stem cells with metastatic capacity in human colorectal cancer. Cell Stem Cell. 2010;6:603-15.

152. Dieter SM, Ball CR, Hoffmann CM, Nowrouzi A, Herbst F, Zavidij O, Abel U, Arens A, Weichert W, Brand K, Koch M, Weitz J, Schmidt M, von Kalle C, Glimm H. Distinct types of tumor-initiating cells form human colon cancer tumors and metastases. Cell Stem Cell. 2011:9:357-65.

153. Fidler IJ, Poste G. The "seed and soil" hypothesis revisited. Lancet Oncol. 2008;9:808.

154. Li S, Li Q. Cancer stem cells and tumor metastasis. Int J Oncol. 2014;44:1806-12

155. Bernards R, Weinberg RA. A progression puzzle. Nature. 2002;418:823.

156. Ramaswamy S, Ross KN, Lander ES, Golub TR. A molecular signature of metastasis in primary solid tumors. Nat Genet. 2002;33:49-54.

157. Hunter K, Welch DR, Liu ET. Genetic background is an important determinant of metastatic potential. Nat Genet. 2003:34:23.

158. Minn AJ, Gupta GP, Siegel PM, Bos PD, Shu W, Giri DD, Viale A, Olshen AB, Gerald WL, Massague J. Genes that mediate breast cancer metastasis to lung. Nature. 2005;436:518-24.

159. Hanniford D, Zhong J, Koetz L, Gaziel-Sovran A, Lackaye DJ, Shang S, Pavlick A, Shapiro R, Berman R, Darvishian F, Shao Y, Osman I, Hernando E. A miRNA-based signature detected in primary melanoma tissue predicts development of brain metastasis. Clin Cancer Res. 2015:21:4903-12.

160. Riester M, Wu H-J, Zehir A, Gönen M, Moreira AL, Downey RJ, Michor F. Distance in cancer gene expression from stem cells predicts patient survival. PLoS One. 2017;12:e0173589.

161. Hermann PC, Huber SL, Herrler T, Aicher A, Ellwart JW, Guba M, Bruns CJ, Heeschen C. Distinct populations of cancer stem cells determine tumor growth and metastatic activity in human pancreatic cancer. Cell Stem Cell. 2008;1:313-23.

162. Hermann PC, Heeschen C. Metastatic cancer stem cells-quo vadis? Clin Chem. 2013:59:1268-9.

163. Lawson DA, Bhakta NR, Kessenbrock K, Prummel KD, Yu Y, Takai K, Zhou A, Eyob H, Balakrishnan S, Wang C-Y. Single-cell analysis reveals a stem-cell program in human metastatic breast cancer cells. Nature. 2015;526:131.

164. Smith BA, Sokolov A, Uzunangelov V, Baertsch R, Newton Y, Graim K, Mathis C, Cheng D, Stuart JM, Witte ON. A basal stem cell signature identifies aggressive prostate cancer phenotypes. Proc Natl Acad Sci. 2015;112:E6544-E52.

165. Psaila B, Lyden D. The metastatic niche: adapting the foreign soil. Nat Rev Cancer. 2009;9:285-93.

166. Sceneay J, Smyth MJ, Möller A. The pre-metastatic niche: finding common ground. Cancer Metastasis Rev. 2013;32:449-64.

167. Kaplan RN, Riba RD, Zacharoulis S, Bramley AH, Vincent L, Costa C, MacDonald DD, Jin DK, Shido K, Kerns SA, Zhu Z, Hicklin D, Wu Y, Port JL, Altorki N, Port ER, Ruggero D, Shmelkov SV, Jensen KK, Rafii S, Lyden D. VEGFR1-positive haematopoietic bone marrow progenitors initiate the pre-metastatic niche. Nature. 2005:438:820-7.

168. Hiratsuka S, Watanabe A, Aburatani H, Maru Y. Tumour-mediated upregulation of chemoattractants and recruitment of myeloid cells predetermines lung metastasis. Nat Cell Biol. 2006;8:1369-75. 
169. Hiratsuka S, Watanabe A, Sakurai Y, Akashi-Takamura S, Ishibashi S, Miyake K, Shibuya M, Akira S, Aburatani H, Maru Y. The S100A8-serum amyloid A3-TLR4 paracrine cascade establishes a pre-metastatic phase. Nat Cell Biol. 2008;10:1349-55.

170. Théry C, Zitvogel L, Amigorena S. Exosomes: composition, biogenesis and function. Nat Rev Immunol. 2002;2:569-79.

171. Lobb RJ, Lima LG, Moller A. Exosomes: Key mediators of metastasis and premetastatic niche formation. Semin Cell Dev Biol. 2017:67:3-10.

172. Zhou W, Fong MY, Min Y, Somlo G, Liu L, Palomares MR, Yu Y, Chow A, O'Connor STF, Chin AR, Yen Y, Wang Y, Marcusson EG, Chu P, Wu J, Wu X, Li AX, Li Z, Gao $\mathrm{H}$, Ren X, Boldin MP, Lin PC, Wang SE. Cancer-secreted miR-105 destroys vascular endothelial barriers to promote metastasis. Cancer Cell. 2014;25:501-15.

173. Schillaci O, Fontana S, Monteleone F, Taverna S, Di Bella MA, Di Vizio D, Alessandro R. Exosomes from metastatic cancer cells transfer amoeboid phenotype to non-metastatic cells and increase endothelial permeability: their emerging role in tumor heterogeneity. Sci Rep. 2017;7:4711.

174. Grange C, Tapparo M, Collino F, Vitillo L, Damasco C, Deregibus MC, Tetta C, Bussolati B, Camussi G. Microvesicles released from human renal cancer stem cells stimulate angiogenesis and formation of lung premetastatic niche. Cancer Res. 2011;71:5346-56.

175. Peinado H, Alečković M, Lavotshkin S, Matei I, Costa-Silva B, Moreno-Bueno G, Hergueta-Redondo M, Williams C, García-Santos G, Nitadori-Hoshino A, Hoffman C, Badal K, Garcia BA, Callahan MK, Yuan J, Martins VR, Skog J, Kaplan RN, Brady MS, Wolchok JD, Chapman PB, Kang Y, Bromberg J, Lyden D. Melanoma exosomes educate bone marrow progenitor cells toward a pro-metastatic phenotype through MET. Nat Med. 2012;18:883-91.

176. Costa-Silva B, Aiello NM, Ocean AJ, Singh S, Zhang H, Thakur Basant K, Becker A, Hoshino A, Mark MT, Molina H, Xiang J, Zhang T, Theilen T-M, García-Santos G, Williams C, Ararso Y, Huang Y, Rodrigues G, Shen T-L, Labori KJ, IMB L, Kure EH, Hernandez J, Doussot A, Ebbesen SH, Grandgenett Paul M, Hollingsworth Michael A, Jain M, Mallya K, Batra SK Jarnagin William R, Schwartz Robert E, Matei I, Peinado H, Stanger BZ, Bromberg J, Lyden D. Pancreatic cancer exosomes initiate pre-metastatic niche formation in the liver. Nat Cell Biol. 2015;17:816.

177. Chaffer $\mathrm{CL}$, Weinberg RA. A perspective on cancer cell metastasis. Science. 2011;331:1559-64.

178. Tam WL, Weinberg RA. The epigenetics of epithelial-mesenchymal plasticity in cancer. Nat Med. 2013;19:1438-49.

179. Aktas B, Tewes M, Fehm T, Hauch S, Kimmig R, Kasimir-Bauer S. Stem cell and epithelial-mesenchymal transition markers are frequently overexpressed in circulating tumor cells of metastatic breast cancer patients. Breast Cancer Res. 2009;11:R46.

180. Theodoropoulos PA, Polioudaki H, Agelaki S, Kallergi G, Saridaki Z, Mavroudis D, Georgoulias V. Circulating tumor cells with a putative stem cell phenotype in peripheral blood of patients with breast cancer. Cancer Lett. 2010;288:99-106.

181. Kasimir-Bauer S, Hoffmann O, Wallwiener D, Kimmig R, Fehm T. Expression of stem cell and epithelial-mesenchymal transition markers in primary breast cancer patients with circulating tumor cells. Breast Cancer Res. 2012;14:R15.

182. Yang $\mathrm{M}-\mathrm{H}$, Imrali $\mathrm{A}$, Heeschen C. Circulating cancer stem cells: the importance to select. Chin J Cancer Res. 2015:27:437.

183. Grillet F, Bayet E, Villeronce O, Zappia L, Lagerqvist EL, Lunke S, et al. Circulating tumour cells from patients with colorectal cancer have cancer stem cell hallmarks in ex vivo culture. Gut. 2016;66:1802-10.

184. Talmadge JE, Fidler IJ. AACR centennial series: the biology of cancer metastasis: historical perspective. Cancer Res. 2010;70:5649-69.

185. Joosse SA, Gorges TM, Pantel K. Biology, detection, and clinical implications of circulating tumor cells. EMBO Mol Med. 2015;7:1-11.

186. Giancotti FG. Mechanisms governing metastatic dormancy and reactivation. Cell. 2013;155:750-64.

187. Eyles J, Puaux A-L, Wang X, Toh B, Prakash C, Hong M, Tan TG, Zheng L, Ong LC, Jin Y. Tumor cells disseminate early, but immunosurveillance limits metastatic outgrowth, in a mouse model of melanoma. J Clin Invest. 2010;120:2030-9.

188. Naumov GN, Akslen LA, Folkman J. Role of angiogenesis in human tumor dormancy: animal models of the angiogenic switch. Cell Cycle. 2006:5:1779-87.

189. Gao XL, Zhang M, Tang YL, Liang XH. Cancer cell dormancy: mechanisms and implications of cancer recurrence and metastasis. OncoTargets Ther. 2017;10:5219.

190. Kleffel S, Schatton T.Tumour dormancy and cancer stem cells: two sides of the same coin?, in Systems Biology of Tumor Dormancy. New York: Springer; 2013. p. 145-79.
191. Sosa MS, Avivar-Valderas A, Bragado P, Wen H-C, Aguirre-Ghiso JA. ERK1/2 and $p 38 \alpha / \beta$ signaling in tumor cell quiescence: opportunities to control dormant residual disease. Clin Cancer Res. 2011;17:5850-7.

192. Gohongi T, Fukumura D, Boucher Y, Yun C-O, Soff GA, Compton C, et al. Tumor-host interactions in the gallbladder suppress distal angiogenesis and tumor growth: Involvement of transforming growth factor $\beta 1$. Nat Med. 1999;5:1203-8.

193. Schober M, Fuchs E. Tumor-initiating stem cells of squamous cell carcinomas and their control by TGF- $\beta$ and integrin/focal adhesion kinase (FAK) signaling. Proc Natl Acad Sci. 2011;108:10544-9.

194. Kobayashi A, Okuda H, Xing F, Pandey PR, Watabe M, Hirota S, Pai SK, Liu W, Fukuda K, Chambers C, Wilber A, Watabe K. Bone morphogenetic protein 7 in dormancy and metastasis of prostate cancer stem-like cells in bone. J Exp Med. 2011;208:2641.

195. Lessard J, Sauvageau G. Bmi-1 determines the proliferative capacity of normal and leukaemic stem cells. Nature. 2003;423:255-60.

196. Liu S, Dontu G, Mantle ID, Patel S, Ahn NS, Jackson KW, Suri P, Wicha MS. Hedgehog signaling and Bmi-1 regulate self-renewal of normal and malignant human mammary stem cells. Cancer Res. 2006;66: 6063-71.

197. Gao D, Nolan DJ, Mellick AS, Bambino K, McDonnell K, Mittal V. Endothelial progenitor cells control the angiogenic switch in mouse lung metastasis. Science. 2008;319:195-8.

198. Lyden D, Young AZ, Zagzag D, Yan W. Id1 and Id3 are required for neurogenesis, angiogenesis and vascularization of tumour xenografts. Nature. 1999:401:670.

199. Stankic M, Pavlovic S, Chin Y, Brogi E, Padua D, Norton L, Massague J, Benezra R. TGF- $\beta$-Id1 signaling opposes Twist1 and promotes metastatic colonization via a mesenchymal-to-epithelial transition. Cell Rep. 2013;5: 1228-42.

200. Pollard JW. Tumour-educated macrophages promote tumour progression and metastasis. Nat Rev Cancer. 2004:4:71

201. Zhang XH-F, Wang Q, Gerald W, Hudis CA, Norton L, Smid M, Foekens JA, Massagué J. Latent bone metastasis in breast cancer tied to Src-dependent survival signals. Cancer Cell. 2009;16:67-78.

202. Chou J, Lin JH, Brenot A, Kim JW, Provot S, Werb Z. GATA3 suppresses metastasis and modulates the tumour microenvironment by regulating microRNA-29b expression. Nat Cell Biol. 2013;15:201.

203. Png KJ, Halberg N, Yoshida M, Tavazoie SF. A microRNA regulon that mediates endothelial recruitment and metastasis by cancer cells. Nature. 2012:481:190

204. Kang Y, Siegel PM, Shu W, Drobnjak M, Kakonen SM, Cordon-Cardo C, Guise TA, Massague J. A multigenic program mediating breast cancer metastasis to bone. Cancer Cell. 2003:3:537-49.

205. Weber GF, Ashkar S, Cantor H. Interaction between CD44 and osteopontin as a potential basis for metastasis formation. Proc Assoc Am Physicians. 1997;109:1-9.

206. Malanchi I, Santamaria-Martínez A, Susanto E, Peng H, Lehr H-A, Delaloye $J$-F, Huelsken J. Interactions between cancer stem cells and their niche govern metastatic colonization. Nature. 2011;481:85.

207. Agliano A, Calvo A, Box C. The challenge of targeting cancer stem cells to halt metastasis. Semin Cancer Biol. 2017:44:25-42.

\section{Submit your next manuscript to BioMed Central and we will help you at every step:}

- We accept pre-submission inquiries

- Our selector tool helps you to find the most relevant journal

- We provide round the clock customer support

- Convenient online submission

- Thorough peer review

- Inclusion in PubMed and all major indexing services

- Maximum visibility for your research

Submit your manuscript at www.biomedcentral.com/submit 